OPEN ACCESS

Edited by:

Antonio Ventosa,

Universidad de Sevilla, Spain

Reviewed by:

Carmen Portillo,

Universidad Rovira i Virgili, Spain Mohammad Ali Amoozegar,

University of Tehran, Iran

*Correspondence: Fernando Martínez-Checa fmcheca@ugr.es

Specialty section

This article was submitted to Evolutionary and Genomic Microbiology,

a section of the journal Frontiers in Microbiology

Received: 15 October 2017 Accepted: 06 June 2018 Published: 21 June 2018

Citation:

Oueriaghli N, Castro DJ, Llamas I, Béjar V and Martínez-Checa F (2018)

Study of Bacterial Community

Composition and Correlation of

Environmental Variables in Rambla Salada, a Hypersaline Environment in

South-Eastern Spain.

Front. Microbiol. 9:1377.

doi: 10.3389/fmicb.2018.01377

\section{Study of Bacterial Community Composition and Correlation of Environmental Variables in Rambla Salada, a Hypersaline Environment in South-Eastern Spain}

\author{
Nahid Oueriaghli ${ }^{1}$, David J. Castro ${ }^{1,2}$, Inmaculada Llamas ${ }^{1,2}$, Victoria Béjar ${ }^{1,2}$ and \\ Fernando Martínez-Checa ${ }^{1,2 *}$ \\ ${ }^{1}$ Microbial Exopolysacharide Research Group, Department of Microbiology, Faculty of Pharmacy, University of Granada, \\ Granada, Spain, ${ }^{2}$ Institute of Biotechnology, University of Granada, Granada, Spain
}

We studied the bacterial community in Rambla Salada in three different sampling sites and in three different seasons and the effect of salinity, oxygen, and $\mathrm{pH}$. All sites samples had high diversity and richness $(\operatorname{Rr}>30)$. The diversity indexes and the analysis of dendrograms obtained by DGGE fingerprint after applying Pearson's and Dice's coefficient showed a strong influence of sampling season. The Pareto-Lorenz (PL) curves and Fo analysis indicated that the microbial communities were balanced and despite the changing environmental conditions, they can preserve their functionality. The main phyla detected by DGGE were Bacteroidetes (39.73\%), Proteobacteria (28.43\%), Firmicutes (8.23\%), and Cyanobacteria (5.14\%). The majority of the sequences corresponding to uncultured bacteria belonged to Bacteroidetes phylum. Within Proteobacteria, the main genera detected were Halothiobacillus and Roseovarius. The environmental factors which influenced the community in a higher degree were the salinity and oxygen. The bacteria belonging to Bacteroidetes and Proteobacteria were positively influenced by salinity. Nevertheless, bacteria related to Alpha- and Betaproteobacteria classes and phylum Firmicutes showed a positive correlation with oxygen and $\mathrm{pH}$ but negative with salinity. The phylum Cyanobacteria were less influenced by the environmental variables. The bacterial community composition of Rambla Salada was also studied by dilution-to-extinction technique. Using this method, 354 microorganisms were isolated. The 16S sequences of 61 isolates showed that the diversity was very different to those obtained by DGGE and with those obtained previously by using classic culture techniques. The taxa identified by dilution-to-extinction were Proteobacteria (81.92\%), Firmicutes (11.30\%), Actinobacteria (4.52\%), and Bacteroidetes (2.26\%) phyla with Gammaproteobacteria as predominant class (65.7\%). The main genera were: Marinobacter (38.85\%), Halomonas (20.2\%), and Bacillus (11.2\%). Nine of the 61 identified bacteria showed less than 97\% sequence identity with validly described species and may well represent new taxa. The number of bacteria in different samples, locations, and seasons were calculated by CARD-FISH, ranging from 54.3 to $78.9 \%$ of the total prokaryotic population. In 
conclusion, the dilution-to-extinction technique could be a complementary method to classical culture based method, but neither gets to cultivate the major taxa detected by DGGE. The bacterial community was influenced significantly by the physico-chemical parameters (specially the salinity and oxygen), the location and the season of sampling.

Keywords: biodiversity, bacteria, hypersaline habitat, Rambla Salada, DGGE, dilution-to-extinction methods

\section{INTRODUCTION}

In hypersaline environments not only, the high salt concentration limits the biodiversity that inhabits them, they also have, depending on the geographical area, low oxygen concentrations, high or low temperatures, and sometimes alkaline conditions. In addition, factors like $\mathrm{pH}$, pressure, low nutrient availability, solar radiation, the presence of heavy metals, and other toxic compounds, may influence their biodiversity (Ventosa, 2004; Bell and Callaghan, 2012). These environments can be thalassohaline or athalassohaline, the first ones have a marine origin and a qualitative composition similar to sea water. In the second ones, the salt composition is similar to the composition of the surrounding geology, topography, and climatic conditions; this is particularly influenced by the dissolution of mineral deposits (Oren, 2002). Extremely and moderately halophilic microorganisms (bacteria and archaea) predominate in hypersaline environments (Ventosa, 2006; Ventosa et al., 2008; Oren, 2011).

Cultivation-based methods are widely used but often in microbial communities in situ, the most abundant members cannot be detected (Rappé and Giovannoni, 2003). During the 1990s and throughout 2000s, the fields of molecular ecology and metagenomics have significantly advanced our knowledge of the genetic diversity and distribution of environmental bacteria. Many new candidate divisions of bacteria and archaea are now recognized due to $16 \mathrm{~S}$ rRNA sequence-based approaches and environmental metagenomics (Curtis et al., 2002). The numerically dominant bacteria of soils and rhizospheres are the Alpha-, Beta-, and Gammaproteobacteria, Actinobacteria, Acidobacteria, Verrucomicrobia, Planctomycetes, Bacteriodetes, and Firmicutes (da Rocha et al., 2009). These findings reveal the vast disparity between the phyla now recognized by molecular methods and those with cultured representatives.

Novel cultivation strategies are addressing the problem of the uncultivable majority of bacteria and have led to resurgence in microbial cultivation. Emerging strategies roughly follow four major lines: (1) Reformulated and improved culturing media employ dilute nutrient media, non-agar matrices, alternative electron receptors and donors, increased incubation times, and modified atmospheres similar to the bacterial environment (Joseph et al., 2003; Schoenborn et al., 2004; Davis et al., 2005). (2) Diffusion chambers grow bacteria in simulated natural environments (Ferrari et al., 2005, 2008; Gavrish et al., 2008; Ferrari and Gillings, 2009). (3) Microbial signaling molecules are added to growth media that replace natural signaling molecules essential for formation of biofilms and natural microbial consortia (Bruns et al., 2003; Stevenson et al., 2004).
(4) High throughput cell separation methods employ either fluorescence activated cell sorting (Zengler et al., 2002, 2005) or dilution-to-extinction (Connon and Giovannoni, 2002) to separate individual bacterial cells to initiate enrichment cultures in dilute natural media.

In order to study the microbial populations in complex habitats has been used several combinations of molecular techniques (Oren, 2003, 2007) among them, the denaturing gradient gel electrophoresis (DGGE) (Muyzer and De Waal, 1994; Muyzer et al., 1996) together with the catalyzed reporter deposition-fluorescence in situ hybridization (CARD-FISH) (Wagner et al., 2003; Amann and Bernhard, 2008). Regarding to the use of independent culture techniques, several authors have studied the prokaryotic diversity in athalassohaline habitats, such as the lake Tebenquiche at Salar de Atacama in Chile (Demergasso et al., 2008), lakes of mountains in the Tibetan plateau (Wu et al., 2006), hypersaline alkaline lakes, such as the Mono lake in California (Humayun et al., 2003) and Wadi An Natrun in Egypt (Mesbah et al., 2007), alkaline evaporation ponds at Sua Pan in Botswana (Gareeb and Setati, 2009), Chott El Jerid, a Tunisian hypersaline lake (Abdallah et al., 2016), saline-alkaline soil located in Ararat Plain (Armenia) (Panosyan et al., 2018) and also in different solar salterns, such as Çamalti Saltern, the biggest artificial marine solar saltern in Turkey (Mutlu and Güven, 2015).

Rambla Salada is a clear example of athalassohaline habitat located in Murcia (south-eastern Spain) with special interest by the European Union and it has been declared as a protected wildfowl zone by its regional government (BORM $10 / 09 / 1998)$. Rambla Salada is a course of $\sim 27 \mathrm{~km}$ that connects two areas of great ecological significance, the Natural Park of Sierra Espuña and the river Segura. It is based on an extensive area of sedimentary materials in which underground water emerged, together with the low rainfall, originates a number of wadis and streams. The salinity in Rambla Salada is due to Miocene evaporitic, gypsiferous and marly deposits (Muller and Hsü, 1987) and the most abundant of ions are $\mathrm{Na}^{+}$and $\mathrm{Cl}^{-}$, followed by $\mathrm{SO}_{4}^{2-}$ and $\mathrm{Ca}^{+2}$ (Ramírez-Díaz et al., 1995). This habitat has been widely studied by our research group since 2005, and five novel halophilic bacterial species have been described so far: Idiomarina ramblicola (Martínez-Cánovas et al., 2004), Halomonas cerina (GonzálezDomenech et al., 2008), Halomonas ramblicola (Luque et al., 2012a) Blastomonas quesadae (Castro et al., 2017), and recently Roseovarius ramblicola (Castro et al., 2018). We have also described its halophilic archaeal community by molecular (Oueriaghli et al., 2013) and classical culture techniques (Luque et al., 2012b), its cultivable halophilic bacteria (Luque et al., 2014) 
and the distribution of Halomonas species by molecular methods (Oueriaghli et al., 2014).

In this work we used the DGGE technique, a cultureindependent method, to study the diversity of the bacterial population and to establish the relationships with environmental variables such as $\mathrm{pH}$, oxygen, salinity, and temperature using multivariate statistical analysis and we compare the diversity obtained by this method with those obtained using cultivation methods and incubation conditions including standard culture media (Luque et al., 2014) and dilution-to-extinction method, a technique that improves slow-growing microorganisms recovery or microorganisms that are apparently uncultivable. This unusual comparison in ecological studies enhances the importance of our study. The bacterial community by molecular methods was also quantified.

\section{MATERIALS AND METHODS}

\section{Sampling Sites Description}

The samples were taken from each of three different points in Rambla Salada at three different periods: June 2006, February, and November 2007. We took 6 samples during each sampling period, 18 samples in total: at Finca La Salina, the samples consisted of soil and watery sediment, from area next to the river (riverbed zone); watery sediment from the water-transfer conduit between the Tagus and Segura rivers (transfer zone) and watery sediment from a saline groundwater spring (upwelling zone) as shown in Table 1. The samples obtained from riverbed and transfer zone showed less salinity than those obtained in the upwelling zone. The salt concentration was higher in June 2006, a season characterized by low rainfall.

The watery sediments were taken from the top $15 \mathrm{~cm}$ of the silt deposits in each sampling point. The samples were stored in sterile polycarbonate tubes and immediately taken to the laboratory, where they were stored at $4{ }^{\circ} \mathrm{C}$ until study, always within $24 \mathrm{~h}$. We determined in situ $\mathrm{pH}$, oxygen, temperature, and conductivity at each sampling site using an ECmeter (TetraConR 325 ), which automatically calculates salinity.

\section{Low-Nutrient Medium}

We used S3, a low-nutrient medium (Sait et al., 2002, 2006) supplemented with 3 and $15 \%$ (w/v) sea-salt solution (RodriguezValera et al., 1981) and $\mathrm{pH}$ adjusted to 5.5, 7, and 10. The composition of the medium is the follow: sea-salt stock $30 \%(\mathrm{w} / \mathrm{v})$ (Rodriguez-Valera et al., 1981), proteose peptone $(0.5 \mathrm{~g})$, trace element solution ${ }^{\dagger}(2 \mathrm{ml})$, vitamins solution $\mathrm{I}^{\ddagger}(2 \mathrm{ml})$, vitamins solution $\mathrm{II}^{\$}(6 \mathrm{ml})$, selenite/tungsten* solution $(2 \mathrm{ml})$, purified $\operatorname{agar}(20 \mathrm{~g})$, DI $\mathrm{H}_{2} \mathrm{O}(1,000 \mathrm{ml})$.

${ }^{\dagger}$ Trace element solution: $\mathrm{HCl} 25 \%(10 \mathrm{ml}), \mathrm{FeCl}_{2} \times 4 \mathrm{H}_{2} \mathrm{O}$ (1.5 g), $\mathrm{CoCl}_{2} \times 6 \mathrm{H}_{2} \mathrm{O}(190 \mathrm{mg}), \mathrm{MnCl}_{2} \times 4 \mathrm{H}_{2} \mathrm{O}$ (100 mg), $\mathrm{ZnCl}_{2}$ (70 mg), $\mathrm{H}_{3} \mathrm{BO}_{3}$ (6 mg), $\mathrm{Na}_{2} \mathrm{MoO}_{4} \times 2 \mathrm{H}_{2} \mathrm{O}$ (36 mg), $\mathrm{NiCl}_{2} \times$ $6 \mathrm{H}_{2} \mathrm{O}(24 \mathrm{mg}), \mathrm{CuCl}_{2} \times 2 \mathrm{H}_{2} \mathrm{O}(2 \mathrm{mg}), \mathrm{DI} \mathrm{H}_{2} \mathrm{O}(1,000 \mathrm{ml})$.

"Vitamins solution I: 4-aminobenzoate $(40 \mathrm{mg})$, Biotin $(10 \mathrm{mg})$ hemicalcium $\mathrm{D}+/$-pantothenate $(100 \mathrm{mg})$, pyridoxamine hydrochloride $(50 \mathrm{mg})$, thiamin hydrochloride (150 mg), cyanocobalamin (100 mg), DI $\mathrm{H}_{2} \mathrm{O}(1,000 \mathrm{ml})$.
\$Vitamins solution II: nicotinic acid (33 mg), DL-6,8-thioctic acid (10 mg), riboflavin (10 mg), folic acid (4 mg), DI $\mathrm{H}_{2} \mathrm{O}$ $(1,000 \mathrm{ml})$.

*Selenite/tungstate solution: $\mathrm{NaOH}(0.5 \mathrm{~g}), \mathrm{Na}_{2} \mathrm{SeO}_{3} \times 5 \mathrm{H}_{2} \mathrm{O}$ (3 mg), $\mathrm{Na}_{2} \mathrm{WO}_{4} \times 2 \mathrm{H}_{2} \mathrm{O}$ (4 mg), DI H $\mathrm{H}_{2} \mathrm{O}(1,000 \mathrm{ml})$.

\section{Dilution-to-Extinction Method}

The cultivation method used in this work was based on the dilution-to-extinction approach (Button et al., 1993; Connon and Giovannoni, 2002; Bruns et al., 2003; Koch et al., 2008). For this purpose, serial dilutions from $1 \mathrm{~g}$ of soil and/or $1 \mathrm{ml}$ of watery sediment were prepared; soil samples were previously sonicated for $30 \mathrm{~s}$, in $10 \mathrm{ml}$ of $\mathrm{S} 3$ medium. The number of microorganisms in each dilution was determined using a Petroff Hausser counting chamber using methylene blue as contrast. A 48-well microtiter plate, containing $490 \mu \mathrm{l}$ of supplemented S3 medium, was inoculated with $10 \mu$ l of the dilution which containing 100 bacteria per milliliter ( $\sim 1$ bacterium per well) and incubated at $25^{\circ} \mathrm{C}$ for 30 days. The bacteria grown in the wells were then isolated in Difco ${ }^{\mathrm{TM}} \mathrm{R} 2 \mathrm{~A}$ agar medium plates (Reasoner and Geldreich, 1985) supplemented with 3 and 15\% (w/v) sea-salt solution (Rodriguez-Valera et al., 1981).

\section{DNA Extraction and Partial Bacterial 16S rRNA Gen Amplification}

Total DNA was extracted, within $24 \mathrm{~h}$ since the samples were taken, from $10 \mathrm{~g}$ of each of samples using the PowerMax ${ }^{\mathrm{TM}}$ Kit for Soil (MO BIO Laboratories) according to the manufacturer's instructions. The primers used for the variable region amplification V1-V3 ( $\sim 500 \mathrm{bp}$ ) of the 16S rRNA gene of domain Bacteria were Bact-8F (5' AGAGTTTGATCCTGGCTCAG $3^{\prime}$ ) (Edwards et al., 1989) and the reverse primer Bact-518R (5' ATTACCGCGGCTGCTGG 3') (Muyzer et al., 1993). A 40-bp-long GC clamp (5'CGC CCG CCG CGC CCC GCG CCC GTC CCG CCG CCC CCG CCC G-3') was attached to the $5^{\prime}$ end of the forward primer to obtain PCR fragments adequate for DGGE analysis (Muyzer et al., 1996). PCR reactions were carried out as described by Oueriaghli et al. (2013). An electroforesis in a $1.5 \% \mathrm{w} / \mathrm{v}$ agarose gel in TBE $1 \times$ buffer was used to separate the PCR products $(5 \mu \mathrm{l})$. Then, the DNA bands were concentrated using Amicon Ultra $0.5 \mathrm{ml} 100 \mathrm{~K}$ centrifugal filters (Eppendorf, Hamburg, Germany).

DNA from pure culture strains isolated by dilution-toextinction methods were extracted with X-DNA Extraction Kit from XtremBiotech S.L. (www.xtrembiotech.com) according to the protocol provided by the company. In this case, PCR amplification of 16S rRNA gene was performed as described elsewhere (Castro et al., 2017).

\section{DGGE}

A universal mutation detection system, Bio-Rad DCODE ${ }^{\mathrm{TM}}$, was used to carry out the denaturing gel gradient electrophoresis. " $\mathrm{A}$ 45 to $60 \%(\mathrm{w} / \mathrm{v})(7 \mathrm{M}$ urea and $40 \%$ deionized formamide) in a gel with $8 \% \mathrm{w} / \mathrm{v}$ polyacrylamide (37.5:1 acrylamide/bisacrylamide) was used. Each sample (1,000-1,600 ng of PCR products) was loaded onto the gel and run for $20 \mathrm{~min}$ at $200 \mathrm{~V}$ and again at $100 \mathrm{~V}$ at $60^{\circ} \mathrm{C}$ for $16 \mathrm{~h}$ in $1 \times$ TAE buffer. The DGGE gel was stained 
TABLE 1 | Physico-chemical parameters at the three sites and sampling seasons in which samples were taken.

\begin{tabular}{|c|c|c|c|c|c|c|}
\hline Sites & Co-ordinates & Sample* & Season & \multicolumn{3}{|c|}{ Physico-chemical parameters } \\
\hline & & S4A & & 4.5 & 83 & 6.8 \\
\hline & & S1B, S2B & February, 2007 & 17.2 & 18.6 & 8.2 \\
\hline & & $\mathrm{S} 1 \mathrm{C}, \mathrm{S} 2 \mathrm{C}$ & November, 2007 & 13 & 11.8 & 8.3 \\
\hline & & $\mathrm{S} 4 \mathrm{C}$ & & 7.9 & 22.2 & 8.0 \\
\hline $\begin{array}{l}\text { Site 2: } \\
\text { Transfer zone }\end{array}$ & $\begin{array}{l}38^{\circ} 07^{\prime} 30.23^{\prime \prime} \mathrm{N} \\
1^{\circ} 07^{\prime} 42.22^{\prime \prime} \mathrm{W}\end{array}$ & S3A & June, 2006 & 1.5 & 62.1 & 8.7 \\
\hline \multirow{2}{*}{$\begin{array}{l}\text { Site 3: } \\
\text { Upwelling zone }\end{array}$} & & S7B, S8B & February, 2007 & 0.6 & 157.6 & 6.7 \\
\hline & & S7C, S8C & November, 2007 & 4 & 151.2 & 7.2 \\
\hline
\end{tabular}

Data from Luque et al. (2012b); Oueriaghli et al. (2013, 2014).

*Type of sample: S1 and S2, soil sample; S3, S4, S7, and S8 watery sediments.

with a 1:10,000 dilution of a stock solution of Syber ${ }^{\circledR}$ Gold (Invitrogen-Molecular Probes) for $45 \mathrm{~min}$. DNA bands were visualized with an UV transilluminator (Molecular Imager ${ }^{\circledR}$, Gel Doc $^{\mathrm{TM}}$ XR System, Bio-Rad). All the type bands were excised from the gel, but among those at the same level, only three were chosen at random for cutting. They were resuspended in $10 \mu \mathrm{l}$ of Milli-Q water and kept overnight at $4{ }^{\circ} \mathrm{C}$. An aliquot of $2 \mu \mathrm{l}$ of the supernatant was reamplified using the original set of primers (Bact-8F without the GC clamp and Bact-518R) under the conditions described above. The PCR products were purified with Illustra ${ }^{\circledR}$ GFX DNA before being sequenced with an ABI PRISM dye-terminator, cycle-sequencing, ready-reaction kit (Perking-Elmer), and an ABI PRISM 377 sequencer (PerkingElmer) according to the manufacturer's instructions" (Oueriaghli et al., 2013).

\section{Phylogenetic Study}

The variable V1-V3 region sequences of the 16S rRNA gene obtained from DGGE and almost complete sequences of the $16 \mathrm{~S}$ rRNA gene from dilution-to-extinction isolates were compared using BLASTN program (Altschul et al., 1997) against the GenBank/EMBL/DDBJ database to determine their phylogenetic affiliations. The sequences were then aligned using ClustalW included in MEGA 7 software (Kumar et al., 2016). The phylogenetic relationships of sequences obtained from the DGGE bands with those from the databases (more than $90 \%$ identity) was studied applying neighbor-joining (NJ), maximum likelihood (ML), and maximum parsimony (MP) methods using MEGA 7. The phylogenetic trees and their robustness were tested by bootstrap analysis with 1000 replicates. Aquifex pyrophilus $\mathrm{Kol5a}^{\mathrm{T}}$ (M83548) was used as out group.

\section{DGGE Fingerprint Analysis}

FPquest v.5.101 software (Bio-Rad ${ }^{\circledR}$ ) was used to standardize and compare the DGGE band patterns and clustering analysis was performed by determining the Pearson and Dice coefficients. Pearson coefficient takes into consideration the intensity of each band, and the Dice coefficient is based on the presence or absence of bands. Dendrograms relating band-pattern similarities were automatically calculated with UPGMA algorithms (unweighted pair-group method with arithmetic mean). The significance of UPGMA clustering was estimated by calculating the cophenetic correlation coefficients (Sokal and Rohlf, 1962).

\section{Diversity Indexes}

Data derived from the presence/absence of bands and from their intensity were exported from the FPquest program to determine the corresponding indexes. We calculated the Shannon-Weaver H' (diversity) and Simpson SI' (dominance) indexes (Shannon and Weaver, 1963; Magurran, 1996) for each DGGE lane using the following equations:

$$
H^{\prime}=\sum_{i=1}^{s} p i \ln p i \quad S I^{\prime}=\sum(p i)^{2}
$$

$S$ corresponds to the total number of bands in a DGGE lane and $p i$ is calculated as $p i=n i$ / $N$; $n i$ is the intensity of each individual band and $N$ the sum of the intensities of all the bands in the analized DGGE lane.

Using the equation $R r=(N 2 \times D g)$ we estimated rangeweighted richness index $(R r)$ where $N$ represents the total number of bands in each DGGE pattern and $D g$ is the denaturing gradient between the first and last band of each 
pattern (Marzorati et al., 2008). As described in our previous work (Oueriaghli et al., 2013), "the evenness of the bacterial community was represented graphically by using the ParetoLorenz $(P L)$ distribution curves on the basis of the DGGE fingerprints (Marzorati et al., 2008) and the bands in each DGGE lane were assorted according to their intensity. The cumulative normalized numbers of bands are represented along the $x$-axis and their respective cumulative normalized intensities are represented along the $y$-axis. The $45^{\circ}$ diagonal represents the perfect evenness of a community in which all the species are equally abundant. To interpret the $P L$ curves numerically and calculate the functional organization index of evenness $(F o)$ we plotted the $y$-axis with the vertical 20\% $x$-axis line (Marzorati et al., 2008). The resulting values indicate the percentage of total band intensities that constitute $20 \%$ of the population. STATGRAPHICS ${ }^{\circledR}$ plus v. 3.2 (STSC, Rockville, MD, USA) was used for the analyses of variance (ANOVA). A significance level of $95 \%(p<0.05)$ was chosen.”

\section{Multivariate Statistical Analysis}

The influence of environmental variables upon bacterial diversity was evaluated by applying the detrended correspondence analysis (DCA) (Lepš and Šmilauer, 2003). Also, according to Oueriaghli et al. (2013) "we applied a CCA analysis using CANOCO 4.5 (Biometris, Wageningen, Netherlands). A Monte Carlo test was used to determinate the significance of each axis and to evaluate the influence of the environmental variables upon the overall distribution of bacterial species and their distribution at each sites and sampling seasons. The significance of the CCA axes was tested by means of 999 unrestricted permutations in order to check the null hypothesis that the bacterial profiles were not related to the environmental variables. The effect of any determined environmental variable was chosen according to its significance level $(p<0.05)$ (Salles et al., 2004; Sapp et al., 2007). Ordination biplots are used to represent the effect of environmental variables on bacterial community structure. The environmental factors are represented as arrows: the length of the arrows indicates the relative importance of that environmental factor in explaining the variation in the bacterial communities, whilst the angle between each arrow and the nearest axis indicates the closeness of the relationship between each other."

\section{CARD-FISH}

Catalyzed reporter deposition (also known as tyramide signal amplification) in situ hybridization (CARD-FISH) was conducted to stain bacterial cells selectively (Pernthaler et al., 2002) and was carry out according to the protocol described by our group in a previous work (Oueriaghli et al., 2013). "The preparation of samples was done by suspending $0.5 \mathrm{~g}$ of soil or watery sediments or $0.5 \mathrm{ml}$ of water in $10 \mathrm{ml}$ of PBS buffer $1 \mathrm{X}$. In the case of soil or watery sediment, the resulting suspension was sonicated using the Ultrasonic (Sonorex Digitec) system for $20 \mathrm{~min}$. Supernatant ( $1 \mathrm{ml}$ of each) were fixed overnight with paraformaldehyde $(2 \%)$ at $4^{\circ} \mathrm{C}$. Cells were filtered and immobilized on $0.2-\mu \mathrm{m}$ pore-size filters (GTTP, Millipore, Eschobron, Germany), embedded in $0.1 \% \mathrm{w} / \mathrm{v}$ agarose and permeabilized by treatment with $10 \mathrm{mg} / \mathrm{ml}$ lysozyme in $50 \mathrm{mM}$
EDTA and $100 \mathrm{mM}$ Tris/ $\mathrm{HCl}$ for $1 \mathrm{~h}$ at $37^{\circ} \mathrm{C}$ (Pernthaler et al., 2002). Filter sections were cut and hybridized with a mixture of $50 \mathrm{ng} / \mu \mathrm{l}$ of horseradish-peroxide-labeled oligonucleotide probe Eub338 (Amann et al., 1995) (2:20 for each section) and buffer hybridization (Pernthaler et al., 2002) for $2.5 \mathrm{~h}$ at $35^{\circ} \mathrm{C}$. For signal amplification, we used fluorochrome-labeled tyramide (1 $\mathrm{mg} / \mathrm{ml}$; FITC) (Pernthaler et al., 2002). All the microbial cells were counterstained with 4',6'diamidino-2-phenylindole (DAPI) at a final concentration of $1 \mathrm{mg} / \mathrm{ml}$ (Snaidr et al., 1997). For microscopy, filters were first embedded in Citifluor ${ }^{\mathrm{TM}}$ (Citifluor Ltd., London, UK), after which the cells were studied under a Leica TCS-SP5 confocal laser scanning microscope (CLSM). Controls with the antisense probe HRP-Non915 were always negative. CARD-FISH stained cells were counted in 20 randomly selected frames using ImageJ software (http://rsb.info.nih.gov/ ij/) (Rhasband, 2010)."

\section{RESULTS}

\section{Dilution-to-Extinction Approach}

Dilution-to-extinction culturing yielded 182 positives microtiter plate wells from a total of 4,800 inoculated wells from which we obtained 354 isolates after re-isolation in R2A medium plates. BLAST searches of the sequences in GenBank revealed that the strains belonged to Proteobacteria (81.92\%), Firmicutes (11.30\%), Actinobacteria (4.52\%), and Bacteroidetes (2.26\%) phyla with Gammaproteobacteria as predominant class (65.7\%). Detailed phylogenetic analysis revealed that the isolates shared 94 to $100 \%$ $16 \mathrm{~S}$ rRNA gene sequence identity with the most closely related validly described species. A total of 61 different species were isolated (Table 2). The most abundant taxa were Marinobacter (38.85\%), Halomonas (20.2\%), and Bacillus (11.2\%). Nine of the 61 identified bacteria showed less than $97 \%$ sequence identity with validly described species and may well represent new taxa.

\section{Analysis of the Bacterial Communities by DGGE Fingerprinting}

DGGE fingerprint of samples were compared by using FPquest software. According to the intensity of the bands, the Pearson's coefficient based dendrogram (Figure 1A) showed two clusters with a $15 \%$ similarity level between them, indicating a low relationship between the two groups of bacteria. The first cluster includes the samples corresponding to June 2006 and November 2007 and the second cluster includes all the samples from February 2007.

Nevertheless, we obtained different results by using the Dice's coefficient, which is based on the presence or absence of bands. As shown in Figure 1B, we found two clusters with $36 \%$ similarity, including the June 2006 samples in the first one and the February and November 2007 samples in the second one. Samples from the upwelling zone (S7 and S8) in the Dice's dendrogram were grouped together during all three seasons studied.

\section{Phylogenetic Analysis of the DNA Sequences of the DGGE Bands}

A total of 67 DGGE bands were successfully reamplified and sequenced (around 500 bp each) from the 90 band classes detected. The identification of phylogenetic neighbors was 
TABLE 2 | Taxa isolated by dilution-to-extinction, identified by comparison of their $16 S$ rRNA gene sequences using BLAST.

\begin{tabular}{|c|c|c|}
\hline Isolate & $\begin{array}{l}\text { GenBank } \\
\text { acc. No. }\end{array}$ & $\begin{array}{l}\text { Closet relatives and } \\
\text { acc. No. }\end{array}$ \\
\hline PL20 & MH266125 & Acinetobacter albensis ANC 4874 (NR_145641) \\
\hline 25-D-8 & MH266126 & Alcanivorax jadensis T9 (NR_025271) \\
\hline M35R & MH266127 & Alkalibacillus silvisoli BM2 (NR_041482) \\
\hline SR54 & MH266128 & Bacillus enclensis SGD-1123 (KF265350) \\
\hline D16_1 & MH266129 & Bacillus halotolerans ATCC 25096 (LPVF01000003) \\
\hline D28_1 & $\mathrm{MH} 266130$ & Bacillus safensis kv2 (MH200636) \\
\hline 16SRL & $\mathrm{MH} 266131$ & Bacillus siamensis KCTC 13613 (AJVF01000043) \\
\hline R63L & MH266132 & Bacillus tequilensis FJAT-40022 (MG905894) \\
\hline SR43 & MH266133 & Bacillus thioparans KmS3200909 (MG011570) \\
\hline M5-FL & MH266134 & Bacillus velezensis CR-502 (AY603658) \\
\hline D22-913 & MH266135 & Blastomonas quesadae 912 (KX990274) \\
\hline R25L & MH266136 & Citreimonas salinaria CL-SP20 (NR_043303) \\
\hline SR37F & MH266137 & Erythrobacter litoralis HMF8222 (KY047411) \\
\hline D11 & MH266138 & Erythrobacter longus DSM 6997 (NR_041889) \\
\hline $2-C-1$ & MH266139 & Erythrobacter marinus HWDM-33 (NR_109054) \\
\hline D40-857 & MH266140 & Flavobacterium jumunjinense HME7102 (NR_109367) \\
\hline M35(1)RL & MH266141 & Halobacillus alkaliphilus SP22 (KX885464) \\
\hline ML35R & MH266142 & Halobacillus halophilus 3 (NR_075035) \\
\hline M45 & $\mathrm{MH} 266143$ & Halomonas alimentaria YKJ-16 (NR_025054) \\
\hline$F-5-2$ & $\mathrm{MH} 266144$ & Halomonas fontilapidosi HMF4436 (KT984005) \\
\hline SR33 & MH266145 & Halomonas gomseomensis M12 (AM229314) \\
\hline SR1 & MH266146 & Halomonas janggokensis FMH54 (KX821765) \\
\hline $28-\mathrm{C}-6$ & $\mathrm{MH} 266147$ & Halomonas stenophila N8 (MG563245) \\
\hline A-10-2 & $\mathrm{MH} 266148$ & Halomonas ventosae NRS2HaP1 (LT221212) \\
\hline L30 & MH266149 & Idiomarina abyssalis MCCC:1A05090 (KM407705) \\
\hline L30-F & $\mathrm{MH} 266150$ & Idiomarina homiensis MCCC:1A05917 (KM407707.1) \\
\hline $26-\mathrm{F}-6$ & $\mathrm{MH} 266151$ & Idiomarina loihiensis GSL 199 (CP005964) \\
\hline $26 f-6$ & MH266152 & Idiomarina ramblicola R22 (NR_025806) \\
\hline L30B & MH266153 & Idiomarina salinarum MCCC:1A02680 (KM407738) \\
\hline D14-37 & $\mathrm{MH} 266154$ & Lysobacter concretionis Ko07 (NR_041003) \\
\hline G-6-2 & MH266155 & Marinobacter adhaerens NIOSSK56\#15(KY604871) \\
\hline $38 \mathrm{CL}$ & MH266156 & Marinobacter algicola VSW110 (KC534310) \\
\hline 14Df & MH266157 & Marinobacter aquaticus M6-53 (LT714149) \\
\hline D-4-4 & $\mathrm{MH} 266158$ & Marinobacter flavimaris D6028 (FJ161304) \\
\hline $17-\mathrm{F}-15$ & MH266159 & Marinobacter guineae M3B (AM503093) \\
\hline $24 f \mathrm{~L}$ & MH266160 & Marinobacter nanhaiticus EAR19 (KU320883) \\
\hline $28-\mathrm{C}-8$ & MH266161 & Marinobacter pelagius KJ-W13 (JQ799110) \\
\hline $27-E-1$ & MH266162 & Marinobacter persicus M9B (NR_109110) \\
\hline D17-1 & MH266163 & Marinobacter salsuginis 11WSA1 (LN794817) \\
\hline $\mathrm{F}-7$ & MH266164 & Marinobacter sediminum UDC408 (HM031994) \\
\hline 709 & MH266165 & Marinobacterium lutimaris AN9 (NR_116590) \\
\hline $16 S F$ & MH266166 & Microbulbifer salipaludis SM-1 (NR_025232) \\
\hline $1-5-E$ & MH266167 & Microbulbifer taiwanensis CC-LN1-12 (NR_108519) \\
\hline D26 & MH266168 & Modestobacter marinus AL27 (KU258224) \\
\hline R14 & MH266169 & Palleronia marisminoris 221-F2 (KJ638254) \\
\hline SR14FL & $\mathrm{MH} 266170$ & Pararhodobacter aggregans D1-19 (NR_115018) \\
\hline $18 \mathrm{RL}$ & MH266171 & Planococcus maritimus Y67 (KU601234) \\
\hline M28-R & MH266172 & Planococcus rifietoensis M8 (CP013659) \\
\hline L43-F & MH266173 & $\begin{array}{l}\text { Pseudoalteromonas issachenkonii KMM } 3549 \\
\text { (CP011030) }\end{array}$ \\
\hline
\end{tabular}

(Continued)
TABLE 2 | Continued

\begin{tabular}{|c|c|c|}
\hline Isolate & $\begin{array}{l}\text { GenBank } \\
\text { acc. No. }\end{array}$ & $\begin{array}{l}\text { Closet relatives and } \\
\text { acc. No. }\end{array}$ \\
\hline L11-R & $\mathrm{MH} 266174$ & Pseudomonas psychrotolerans Pp1 (MH233970) \\
\hline 23-B-5 & $\mathrm{MH} 266175$ & Pseudoruegeria aquimaris SW-255 (NR_043932) \\
\hline M6RL & $\mathrm{MH} 266176$ & Rheinheimera pacifica NBRC 103167 (NR_114230) \\
\hline $6 F L$ & MH266177 & Rheinheimera tangshanensis RB-213 (JQ361154) \\
\hline 13-B-7 & $\mathrm{MH} 266178$ & Roseovarius mucosus DFL-24 (NR_042159) \\
\hline D-6-6 & MH266179 & Roseovarius nubinhibens SM25 (LT600603) \\
\hline 12-D-7 & MH266180 & Roseovarius pacificus 81-2 (NR_043564) \\
\hline $6-\mathrm{F}-3$ & $\mathrm{MH} 266181$ & Roseovarius tolerans EL-164 (KP723471) \\
\hline 20-B-2 & MH266182 & Sediminimonas qiaohouensis YIM B025 (EU878004) \\
\hline $4-\mathrm{C}-4$ & MH266183 & Thalassospira profundimaris WP0211 (NR_042766) \\
\hline $6-D-7$ & MH266184 & Wenzhouxiangella marina 4S-CH-S3-s2 (MG264256) \\
\hline M34FL & MH266185 & Winogradskyella arenosi R60 (NR_041689) \\
\hline
\end{tabular}

carried out by the BLASTN (Altschul et al., 1997) program against the GenBank/EMBL/DDBJ database containing type strains with validly published prokaryotic names and representatives of uncultured phylotypes. The results are shown in Table 3. Clustering was determined using the neighborjoining, maximum-parsimony, and maximum-likelihood algorithms giving the three, similar topologies and bootstrap values. The neighbor-joining phylogenetic tree (Figure 2) shows four main clusters, corresponding to the phyla Bacteroidetes, Proteobacteria, Firmicutes, and Cyanobacteria. Within the phyllum Proteobacteria, we found four groups, corresponding to Alpha-, Beta-, and Gammaproteobacteria classes. Figure 3 shows the bacterial diversity found by molecular techniques (DGGE) (a) in comparison to that identified by us in a previous work (Luque et al., 2014) in the same habitats, using classical culture techniques (b) and by a dilution-to-extinction approach (c). The relative abundance of identified sequences during the three seasons in Rambla Salada indicated that Bacteroidetes (39.73\%) was the most abundant phylum with $46.07,37.42$, and $35.72 \%$ of relative abundance percentage in June 2006 and February and November 2007, respectively, followed by Proteobacteria (28.43\%), showing higher proportion in samples taken in November 2006 (30.23\%), and Firmicutes (8.23\%) and Cyanobacteria (5.14\%) with the highest proportion in samples taken in February 2007 (9.73 and 9.13\%, respectively). A group of unidentified bacteria was also detected. All the sequences related with Bacteroidetes were identified as uncultured bacteria, while Proteobacteria included sequences related with species belonging to different genera, such as, Idiomarina, Alteromonas, Halothiobacillus, Ectothiorhodospira, Caulobacter, Porphyrobacter, Azospirillum, Rhodovibrio, Azoarcus, Comamonas, Methylibium, Alkalilimnicola, Salipiger, Roseivivax, Oceanicola, Paracoccus, and Roseovarius.

\section{Analysis of Diversity Indexes}

The average number of bands obtained in the DGGE per sample were 25 , with a minimum of 14 bands in one sample from the upwelling zone (S8) taken in June 2006 and a maximum of 36 
A

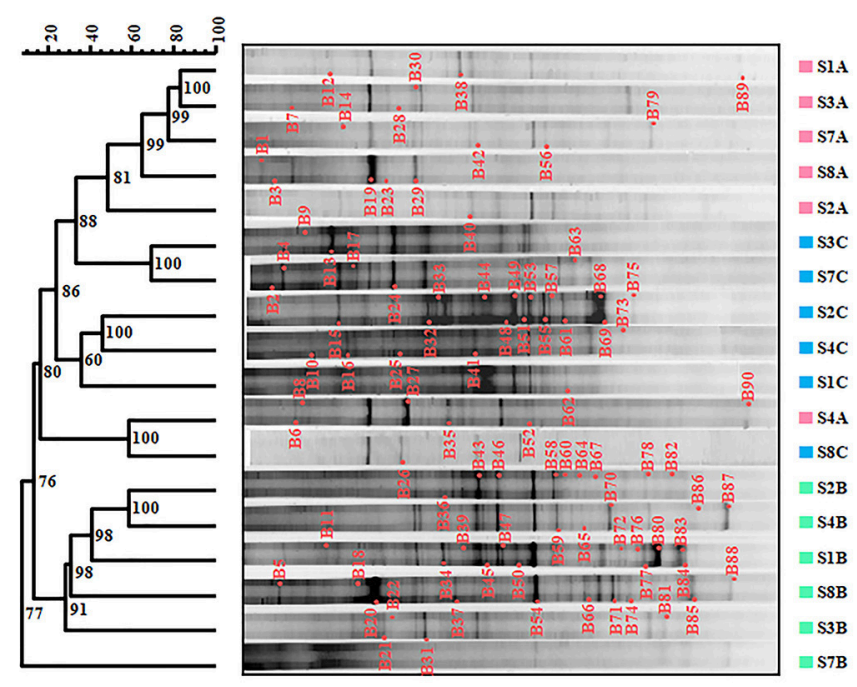

B

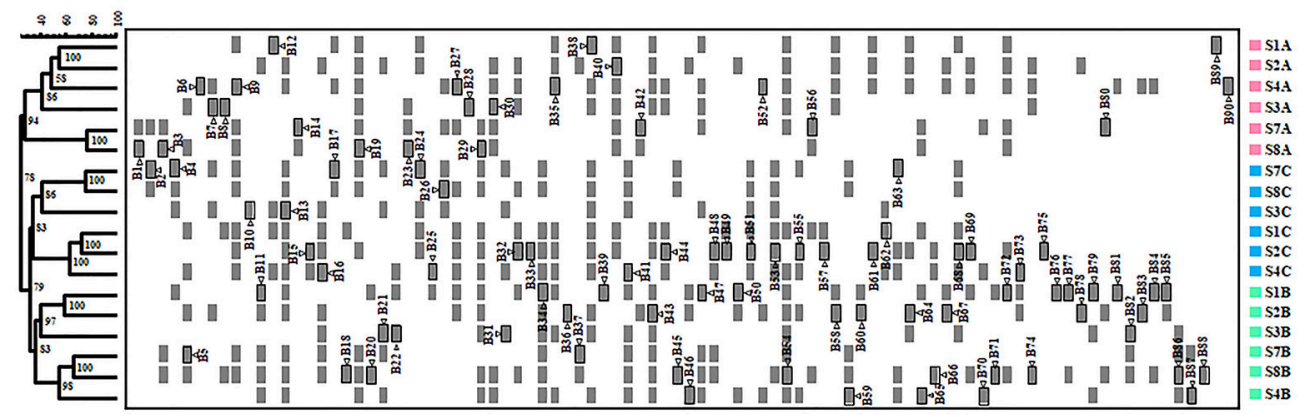

FIGURE 1 | Bacteria in Rambla Salada analyzed by DGGE. (A) Pearson coefficient-based analysis. (B) Dice coefficient-based analysis. The scale bar indicates the percentage of similarity. Numbers in nodes represent the cophenetic correlation coefficient values. Triangles followed by gray shaded squares bands re-amplified and sequenced to conduct the phylogenetic study. S1A to S8A, sampling sites in June 2006; S1B to S8B, sampling sites in February 2007, and S1C to S8C, sampling site in November 2007.

bands from the same zone (S8) taken in February 2007. The diversity and richness of the bacterial communities depended on the sampling season and showed average $R r$ index values ranging from $41.36 \pm 25.95$ to $74.14 \pm 38.31$ (Table 4) with high average richness-index values $(R r>30)$ in the three seasons.

The Shannon-Weaver index values $\left(H^{\prime}\right)$ were $2.22 \pm 0.34,2.60$ \pm 0.36 , and $2.63 \pm 0.24$ for the June 2006, February 2007, and November 2007 samples respectively. The Simpson index (SI'), which represents dominance and is inversely proportional to the Shannon-Weaver index, were $0.13 \pm 0.07,0.11 \pm 0.06$, and 0.09 \pm 0.02 respectively. ANOVA analysis $(p<0.05)$ revealed that there were significant differences in the diversity indexes from one season to another (Table 4).

The functional organization of the bacterial communities was carried out using the Fo index (Table 4) and the Pareto-Lorenz distribution curve (Figure 4). In the samples corresponding to June 2006, 20\% of the bands showed Fo values of $60.50,55.04$, and $63.02 \%$ in the riverbed, rivertransfer and upwelling zones respectively, and the average value of the cumulative band intensities being $59.52 \%$
(Figure 4A). Twenty per cent of the bands detected in the February 2007 samples represented 60.55, 35.77, and $65.13 \%(53.81 \%$ on average $)$ of the accumulative band intensities (Figure 4B), and another 20\% of the bands represented $60.55,52.29$, and $55.96 \%$ of the accumulative band intensities (52.26\% on average) in the November 2007 samples (Figure 4C).

\section{Relationships Between the Composition of Bacterial Communities and Environmental Variables}

DCA analysis were carried out to determine whether our data were unimodal or linear. DCA analysis showed that the data (2.841) exhibited an unimodal or lineal response to the environmental variables (Lepš and Šmilauer, 2003), so we decided to apply a CCA analysis. Table 5 shows the eigen values, the cumulative percentage variance in species data and the cumulative variance in the species-environment relationship along the three axes of the CCA analysis. 
TABLE 3 | 16 S gene sequences obtained from the bands in DGGE and percentages of identity with their closest relatives.

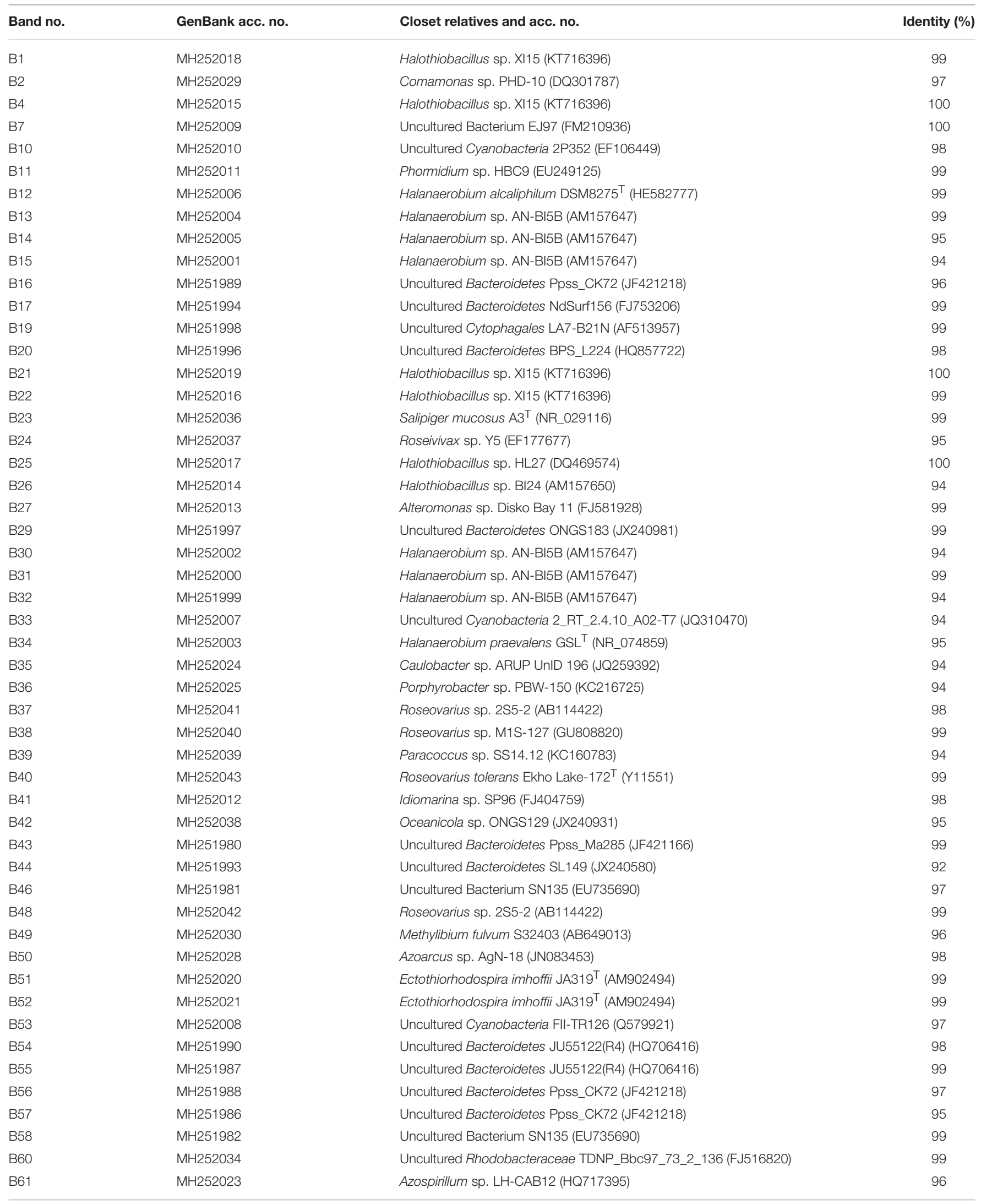


TABLE 3 | Continued

\begin{tabular}{|c|c|c|c|}
\hline Band no. & GenBank acc. no. & Closet relatives and acc. no. & Identity (\%) \\
\hline B62 & MH252035 & Uncultured Rhodobacteraceae TDNP_Bbc97_73_2_136 (FJ516820) & 99 \\
\hline B63 & MH252031 & Methylibium fulvum S32403 (AB649013) & 94 \\
\hline B68 & $\mathrm{MH} 251992$ & Uncultured Bacteroidetes JU55122(R4) (HQ706416) & 99 \\
\hline B69 & MH252027 & Rhodovibrio sodomensis DSM9895 (FR733704) & 99 \\
\hline B73 & MH251978 & Uncultured Bacterium SN151 (EU735696) & 99 \\
\hline B74 & MH251977 & Uncultured Bacterium SN151 (EU735696) & 99 \\
\hline B75 & MH251995 & Uncultured Bacteroidetes HAHS13.3 (HQ396933) & 99 \\
\hline B76 & MH251983 & Uncultured Bacterium SN135 (EU735690) & 99 \\
\hline B77 & MH251991 & Uncultured Bacteroidetes JU55122(R4) (HQ706416) & 97 \\
\hline B85 & MH252026 & Rhodovibrio salinarum JA281 (FM177506) & 98 \\
\hline
\end{tabular}

Based on the $5 \%$ level in a partial Monte Carlo permutation test, the value for oxygen and salinity were significant $(P<0.05)$, providing 75 and $41.2 \%$, respectively, of the total CCA explanatory power. Therefore, the data concerning the environmental factors contributing to the model were ranked in the following order: oxygen, salinity, and finally $\mathrm{pH}$. Species environment correlation for the three axes was more than 0.93 , suggesting that bacterial community were strongly correlated with these environmental factors. Figure 5 shows the influence of the environmental variables upon the diversity of bacterial community in the three seasons studied (Figure 5A) and also in relation to the sampling site (Figure 5B). Figure $\mathbf{5 A}$, in which each environmental variable is represented by an arrow, the projection of any given taxon along an axis shows the level of the variable where the taxon is most abundant. CCA analysis showed a positive correlation with salinity on members belonging to the phylum Bacteroidetes, as well as Gammaproteobacteria class. Most of the uncultured bacteria also correlated positively with this environmental factor. Nevertheless, all the bacteria related to Alpha- and Betaproteobacteria class and phylum Firmicutes showed a positive correlation with oxygen and $\mathrm{pH}$ and negative with salinity. Finally, the phylum Cyanobacteria were less influenced by the environmental variables.

As seen in Figure 5B, in relation with the location of samples there were two different groups: group A, that included the upwelling zone samples (S7 and S8), showing a positive correlation with salinity and negative correlation with oxygen and $\mathrm{pH}$, and group $\mathrm{B}$, that included riverbed zone and transfer zone samples, showing a positive correlation with $\mathrm{pH}$ and oxygen. S3A sample, from the river-transfer conduit, taken in June 2006, is completely different from all the other samples analyzed and thus has not been taken into consideration in our interpretation of the results.

\section{Quantitative Analysis of the Microbial Community as a Whole and its Bacterial Component}

Total microbial cells in Rambla Salada detected with DAPI staining were $6.1 \times 10^{8}, 6.7 \times 10^{8}$, and $7.1 \times 10^{8}$ cells $/ \mathrm{ml}$ in February 2007, November 2007, and June 2006, respectively (CFU/ml) (Figure 6B). CARD-FISH, using universal probes for the Bacteria domain, allowed us to know that the bacteria population in Rambla Salada were $3.9 \times 10^{8}$ in June 2006, $4.3 \times$ $10^{8}$ in November 2007, and $4.8 \times 10^{8}$ cells $/ \mathrm{ml}$ in February 2007 . Figure 6A shows a photograph of bacterial cells hybridized with universal bacterial probe (Eub338-HRP-FITC) in samples from riverbed zone in February 2007.

\section{DISCUSSION}

Microbial diversity studies has progressed increasingly since the inclusion of molecular techniques that allow to obtain the fingerprinting based on the 16S ribosomal RNA gene analysis, such as the Denaturing Gradient Gel Electrophoresis (DGGE). DGGE fingerprinting is a useful molecular tool due to number of bands and their intensities are related to diversity (Muyzer et al., 1993). Additionally, clustering and ordination methods can include environmental parameters that help to evaluate the impact of different factors on the community composition and structure (Besemer et al., 2005). Nevertheless, in spite of DGGE has significant limitations that should be considered like the possible bias introduced through the DNA extraction, PCR amplification, selection of universal primers and different number of rRNA gene copies (Neufeled and Mohn, 2006) the technique is still used to get an idea of the predominant bacterial population in a habitat (Tang et al., 2016; Yin et al., 2016; Garofalo et al., 2017; Huang et al., 2017; Panosyan et al., 2018). Moreover, 


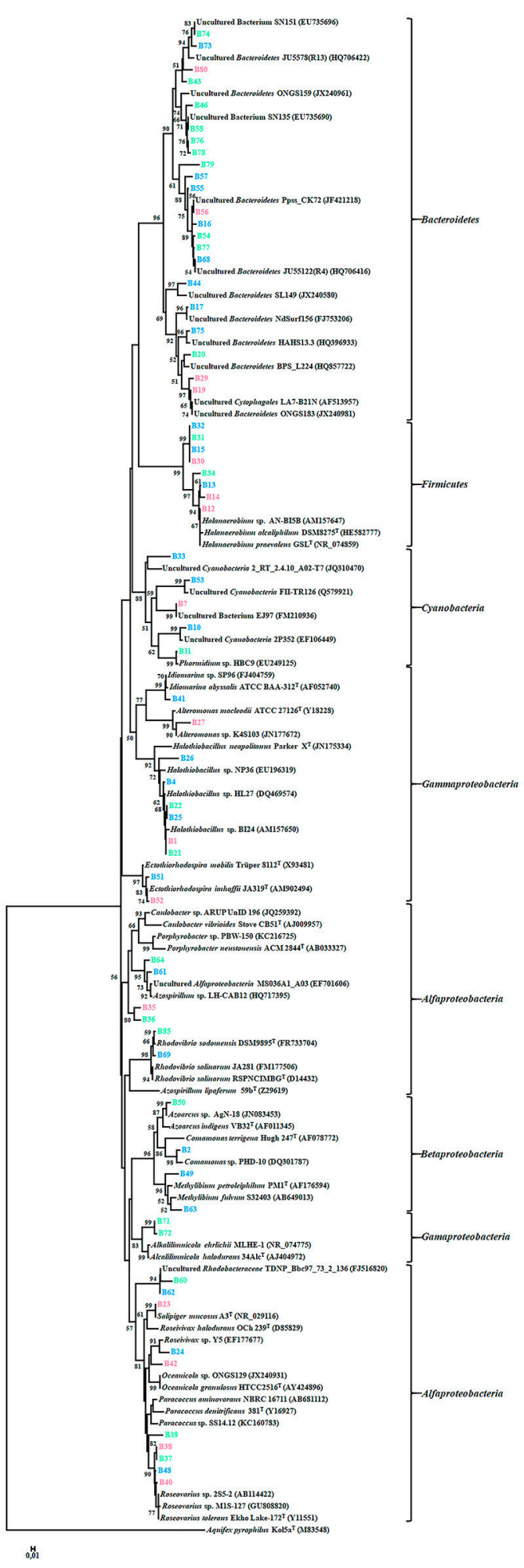

FIGURE 2 | Neighbor-joining phylogenetic tree showing the relationships between the 67 bacterial sequences from the DGGE bands and the most similar sequences retrieved from the GenBank/EMBL/DDBJ database. The scale bar indicates $0.01 \%$ divergence. Bootstrap values over $50 \%$ are shown in nodes.
DGGE technique permit use the FPquest software to determine several diversity indexes as we explained below.

In this work we studied the bacterial community of Rambla Salada by DGGE and by dilution-to-extintion culture and we compare these data with those obtained by our group with classical culture media (Luque et al., 2012b). Moreover, we determine the correlation of geographical location, season and physic-chemical parameters (oxygen, salinity, and $\mathrm{pH}$ ) in the bacterial community.

The results from the DGGE fingerprint analyzed by FPquest software revealed time differences (sampling period) in the bacterial community. Dendrogram showed in Figure 1A, based on band intensities (Pearson's coefficient) clustered together samples gathered in June 2006 and November 2007 while samples taken in February 2007 were not related. In contrast, Dice's coefficient (Figure 1B) showed a clear partition of the three sampling periods in the bacterial community in Rambla Salada. As shown in Figure 1A, the diversity profile of bacteria obtained in June 2006 differed significantly from the ones taken in February and June 2007, however, the presence-absence and intensity of the bands were similar for all of these periods. Thus, UPGMA group method carried out with Pearson's coefficient was more sensitive to intensity relative variations of the bands (Huys and Swings, 1999). More conservative rates, as Dice's similarity coefficient (Schwalbach et al., 2005; Hewson et al., 2006a,b) are recommended for genetic fingerprinting like DGGE technique. In spite of the use of a variety of similarity rates, different results in the samples clustering, Pearson and Dice coefficients revealed differences in the bacterial community, depending on the sampling time period. Nevertheless, no relationship could be established between the sample type and a specific taxon.

We can conclude that sample type (soil or watery sediment) or sampling area does not seem to affect the bacterial clustering, with the exception of samples from the upwelling area (S7 and S8) that were clustered together in the different sampling period, as showed in the dendrogram obtained by the Dice index. The upwelling zone is a sulfurous saline water pool with particular characteristics due to the high amount of chlorides and the great sulfate proportion from plaster. This water pool stays constant along the year and it has a regular salt concentration, which might be the reason that the biodiversity found in this area was analogous but different of the other sampling sites (Table $\mathbf{1}$ ).

The statistical study carried out over the different sampling areas and periods using various diversity indexes, confirmed the relation between the microbial communities found and the sampling periods, being June 2006 community the one with greatest difference. Regarding $R r$, February and November 2007 had the highest richness values ( $74.14 \pm 38.31$ and $58.73 \pm 26.86$, respectively (Table 4). $R r$ values above 30 are typical in microbial diverse environments, according to Marzorati et al. (2008).

When applying Shannon-Waver (H') diversity index (Shannon and Weaver, 1963), which take the number of species present in the study area (species richness) and the number of individual of every species into account, similar results were reported. In this case, February and November 2007 were the seasons with the highest diversity values 


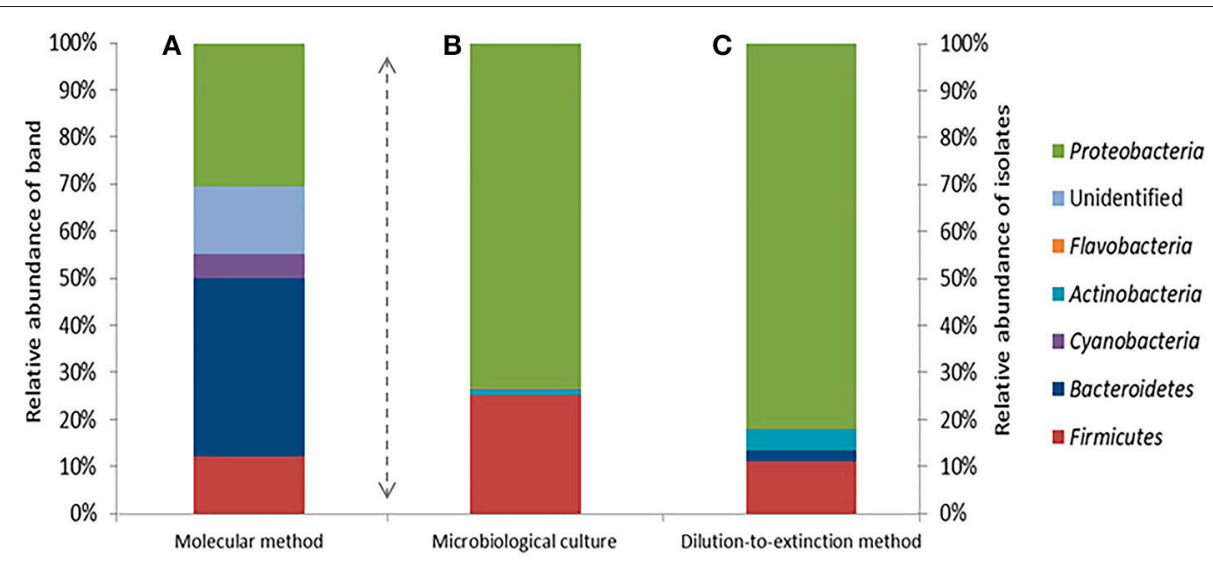

FIGURE 3 | Bacterial diversity determined by analysis of the DGGE bands (A), standard microbiological culture-dependent methods (B) (Data from Luque et al., 2014) and dilution-to-extinction method (C).

TABLE 4 | Diversity indexes of bacterial communities in Rambla Salada at the three sites and sampling seasons.

\begin{tabular}{|c|c|c|c|c|}
\hline Sampling season & Range-weighted richness (Rr) & Functional organization (Fo) & Shannon-Weaver $\left(H^{\prime}\right)$ & Simpson's (SI') \\
\hline June-06 & $41.36 \pm 25.95^{\star}$ & $59.52 \% *$ & $2.22 \pm 0.34^{\star}$ & $0.13 \pm 0.07^{\star}$ \\
\hline February-07 & $74.14 \pm 38.31$ & $53.81 \%$ & $2.60 \pm 0.36$ & $0.11 \pm 0.06$ \\
\hline LSD $\ddagger$ & 0.0365 & 0.0128 & 0.0385 & 0.0251 \\
\hline
\end{tabular}

*Significant differences among the three sampling seasons.

${ }^{\ddagger}$ Least-significant difference at $p<0.05$.
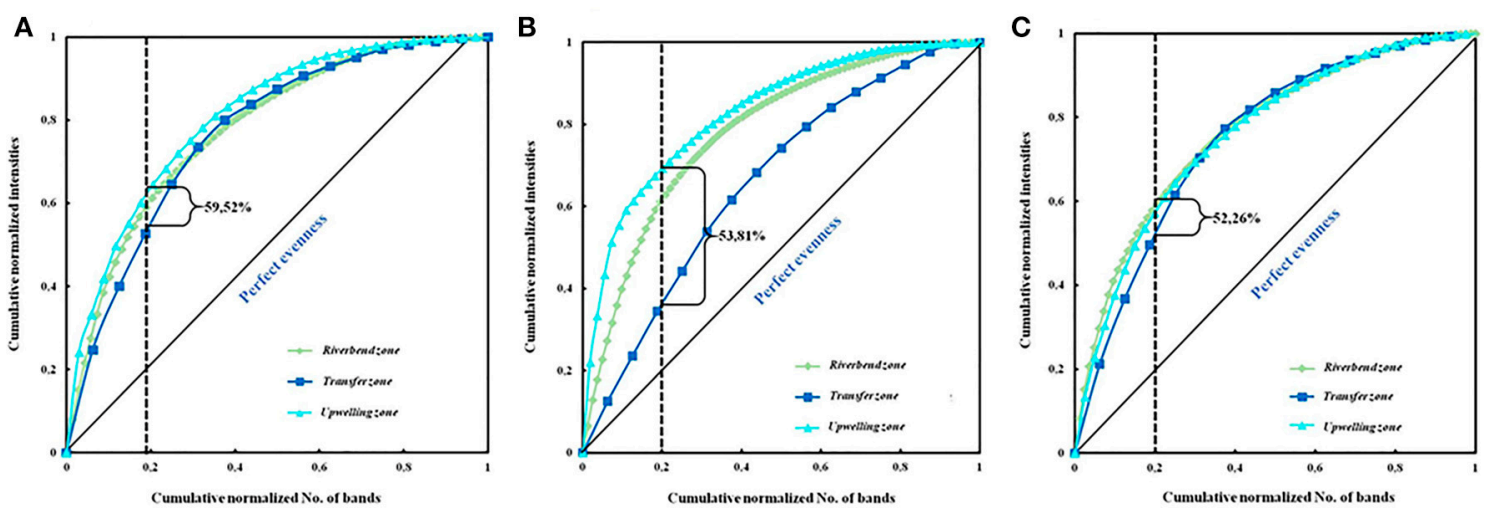

FIGURE 4 | Pareto-Lorenz distribution curves based on the DGGE fingerprints of the bacterial community in the different sampling zones in June 2006 (A), February 2007 (B), and November 2007 (C). The vertical lines at the $0.2 x$-axis are plotted to determine the Pareto values (Fo).

$(2.60 \pm 0.36$ and $2.63 \pm 0.24$, respectively); these values were above 2.5 , indicating that a high bacterial diversity was present in Rambla Salada. Luque et al. (2014) obtained similar results analyzing the bacterial diversity using traditional culture-dependent methods in the same areas and time periods.

Simpson index $(S I)$ was applied to determine the species dominance within a sample, is based on the number of species and their abundance. Dominance was the lowest in November $2007(0.09 \pm 0.02)$ and the highest in June $2006(0.13 \pm 0.07)$.
These results confirm that dominance decreases concomitantly with an increase in diversity (Magurran, 1996).

The highest richness and diversity values were detected in samples taken from riverbed zone in February and November 2007 with a low salt and high oxygen concentrations. The high richness and diversity values were probably related to these two environmental factors as confirmed by using CANOCO. In fact, in this analysis, salinity and oxygen were the most significant environmental factors that affected the distribution and composition of the bacterial community. 
TABLE 5 | Summary of CANOCO results.

\begin{tabular}{lccc}
\hline Axes inertia & $\mathbf{1}$ & $\mathbf{2}$ & $\mathbf{3}$ \\
\hline Eigenvalues & 0.277 & 0.277 & 0.168 \\
Specie-environment correlations & 0.943 & 0.973 & 0.930 \\
Cumulative percentage variance of species data & 9.7 & 17.7 & 23.6 \\
Cumulative percentage variance of & 41.2 & 75.0 & 100.0 \\
species-environment relation & & &
\end{tabular}

Jiang et al. (2007) demonstrated that the salinity was the dominant factor influencing the composition and community structure of the bacteria population in a hypersaline lake located in Tibet, where the sample with highest salt concentration exhibited the least diversity. Similar results have been previously reported by different authors (Benlloch et al., 2002).

Bacterial community uniformity was determined by ParetoLorenz (PL) curves, showing the majority of the analyzed samples, medium Fo values (ranging from 40 to 60\%) (Figure 4 and Table 4), indicating that the communities were balanced and could, therefore, potentially deal with changing environmental conditions and preserve their functionality (Marzorati et al., 2008). Samples taken in June 2006 and February 2007, however, seem to have similar biogeographical patterns and Fo index above $60 \%$, indicating that the bacterial community in this zone and time period was more specialized, due to having a few dominant species, whilst the others were only represented by a few cells (Marzorati et al., 2008).

Ninety DGGE band classes in total were detected, and 67 of them were sequenced. Identified sequences were affiliated to phyla Bacteroidetes, Proteobacteria (Alfa-, Beta-, and Gammaproteobacteria classes), Firmicutes, and Cyanobacteria (Figure 2 and Table 3). Different authors have reported that in saline and hypersaline habitats, the most abundant groups of cultivable bacteria are affiliated to Bacteroidetes, Proteobacteria, and Firmicutes phyla (Benlloch et al., 2002; Mouné et al., 2003; Dong et al., 2006; Jiang et al., 2006, 2007; Maturrano et al., 2006; Mesbah et al., 2007; Mutlu et al., 2008; Hollister et al., 2010; Makhdoumi-Kakhki et al., 2012). The cultured bacteria present in soils and sediments, taken around the world from saline and hypersaline environments, mainly belong to the phylum Proteobacteria (Hollister et al., 2010; López-López et al., 2010; Swan et al., 2010; Nemergut et al., 2011; Luque et al., 2014). Nevertheless, our results showed differences between the bacterial community determined by molecular techniques and those obtained by culture-dependent methods (dilution-toextinction and classical methods) (Luque et al., 2014). Maturrano et al. (2006) and (Panosyan et al., 2018) also showed differences between the biodiversity studied by molecular methods and classical methods in different hypersaline habitats.

In this study, $39.73 \%$ of the relative abundance of the total bacterial community was affiliated to uncultured taxa belonging to phylum Bacteroidetes, indicating that it was the dominant group. These features agreed with the results previously obtained by Makhdoumi-Kakhki et al. (2012), who reported that 59\% of the identified sequences in Aran-Bidgol Lake (Iran) were affiliated to phylum Bacteroidetes, corresponding the $40 \%$ to
Salinibacter genus. Salinibacter has been described as the most abundant taxon in different solar salterns located in Mallorca and Alicante, Spain (Antón et al., 1999, 2000; Rosselló-Mora et al., 2003) and in Çamalti saltern, the biggest artificial marine solar saltern in Turkey (Mutlu and Güven, 2015), as well as in different hypersaline lakes (Maturrano et al., 2006; Mesbah et al., 2007; Mutlu et al., 2008; Makhdoumi-Kakhki et al., 2012). Nevertheless, we could not detect Salinibacter in soil or watery sediments in Rambla Salada. All the sequences affiliated to Bacteroidetes were identified as non-cultivated species. Therefore, salt concentrations of Rambla Salada (1.1-15.8\%, w/v) may not be suitable for Salinibacter to growth. Phylum Bacteroidetes was widely spread in every sampling area and season, even in low, medium and high salt concentrations samples. These results agreed with those obtained using CANOCO software, in which most of the sequences affiliated to Bacteroidetes were in salinity axis (Figure 5A). Bacteroidetes dominance in saline and hypersaline environments has been previously reported (Antón et al., 1999, 2000; Rosselló-Mora et al., 2003; Makhdoumi-Kakhki et al., 2012) and its presence increases with the increase of salinity (Benlloch et al., 2002; Demergasso et al., 2004, 2008; Jiang et al., 2006).

Proteobacteria was the second most abundant phylum, including members of Alpha-, Beta-, and Gammaproteobacteria classes. Wu et al. (2006) demonstrated that when salinity increase, the relative abundance of Betaproteobacteria class members decreases, but the relative abundance of Apha- and Gammaproteobacteria taxa increases. These results agreed with different studies carried out in continental waters (Böckelmanna et al., 2000; Brümmer et al., 2000), estuaries (del Giorgio and Bouvier, 2002; Kirchman et al., 2005; Henriques et al., 2006; Zhang et al., 2006), solar salterns (Benlloch et al., 2002), and a DGGE study in the soda saline crater lake from Isabel island, in the eastern tropical Pacific coast of Mexico (Aguirre-Garrido et al., 2016). In our study, the sequences affiliated to class Alpha- and Betaproteobacteria showed a negative correlation with salinity and positive with oxygen and $\mathrm{pH}$, whilst class Gammaproteobacteria was positively related to salinity. So, the correlation with salinity is the same that above studies in the case of sequences affiliated to Beta- and Gammaproteobacteria, however the Alphaproteobacteria showed a different correlation with salinity. Nevertheless, Langenheder et al. (2003) demonstrated that Alpha-, Beta-, and Gammaproteobacteria classes were more abundant in low saline conditions. Jiang et al. (2007) reported that Betaproteobacteria members were the most abundant class, within the Proteobacteria phylum, in different lakes located in Tibet, northeast China, with high salt concentration, and no variations of the relative abundance of Alpha- and Gammaproteobacteria members along the salinity gradients were found.

The relative abundance of phylum Firmicutes represents $8.23 \%$ of the total bacterial community in Rambla Salada. Different authors reported that Firmicutes taxa only represents 11 to $25 \%$ of the phylotypes detected in most of the saline and alkaline lakes (Scholten et al., 2005; Jiang et al., 2006; Mesbah et al., 2007). In a study carried out in Aran-Bidgol 

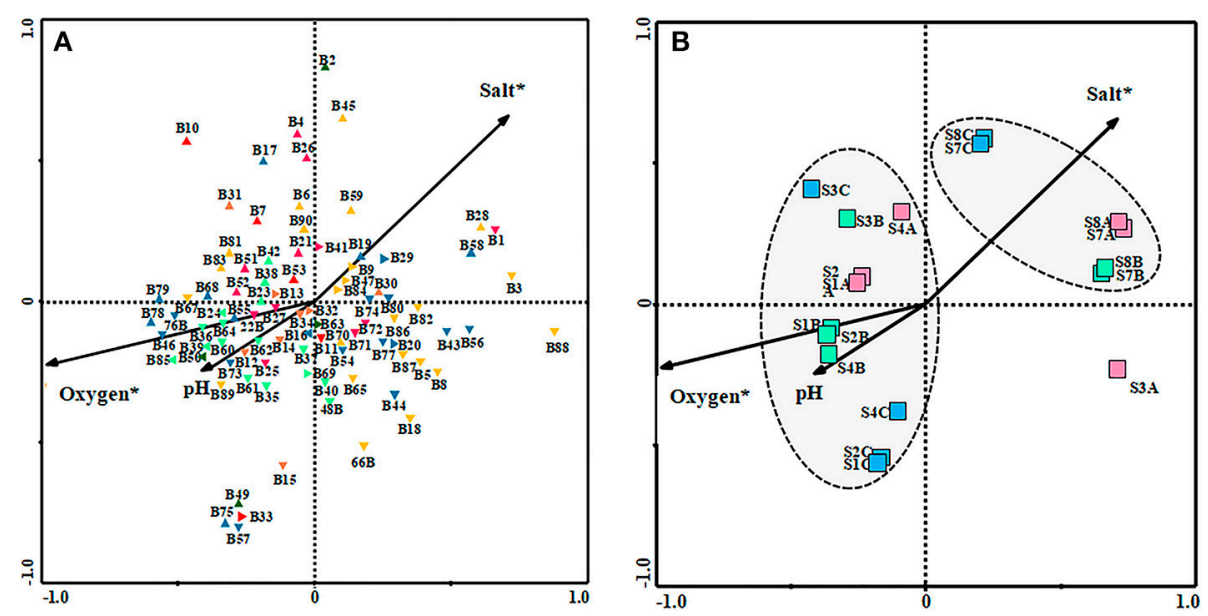

FIGURE 5 | Canonical correspondence analysis (CCA) ordination diagram (biplot) of bacterial species with environmental variables [salt, pH and oxygen] (A) and of them with the site and sampling season [SA (June 2006), SB _ (February 2007), SC — (November 2007). (S1, S2, and S4: Riverbend zone; S3: River-transfer zone; $S 7$ and S8: Upwelling zone)] (B). Environmental variables are indicated as arrows. Environmental variables marked with asterisks are significant $(p<0.05)$.

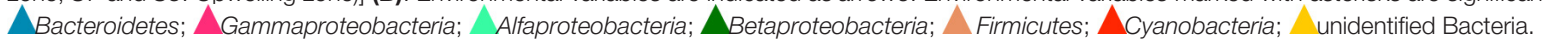

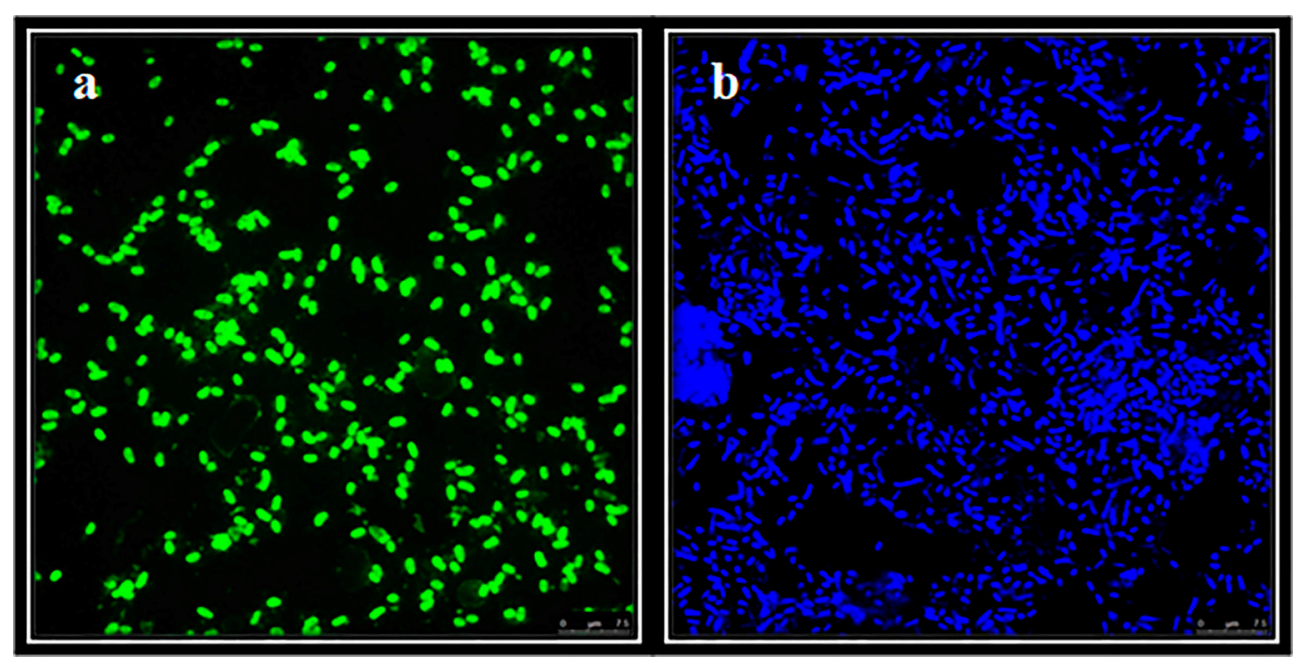

FIGURE 6 | CARD-FISH of samples from Rambla Salada. FITC (total bacteria) counts from riverbed zone in February 2007 (A) and DAPI (total population) (B). Image of bacterial cells visualized with a Leica TCS-SP5 CLSM. Scale bars, $7.5 \mu \mathrm{m}$.

Lake (Iran), 6\% of the relative abundance of taxa belonged to phylum Firmicutes (Makhdoumi-Kakhki et al., 2012). Nevertheless, in a study carried out in a saline-alkaline soils in Ararat Plain (Armenia) that combined DGGE and culturedependent method a dominance of Firmicutes populations inhabited by moderately halophilic bacilli belonging to the genera Halobacillus, Piscibacillus, Bacillus, and Virgibacillus was found (Panosyan et al., 2018). In Rambla Salada, the DGGE bands identified as Firmicutes members were negatively related with salinity, except the B30 band (94\% of identity with Halanaerobium). Jiang et al. (2007) corroborated our results since they reported that the abundance of Firmicutes taxa was high in low salt concentration areas but low in high concentration areas.
The relative abundance of phylum Cyanobacteria in Rambla Salada was $5.14 \%$. This percentage was also agree with Makhdoumi-Kakhki et al. (2012) who reported that $8 \%$ of clones retrieved from Aran-Bidgol Lake (Iran) were affiliated to this phylum.

On the other hand, by using classic culture methods, we determined that the bacterial population in Rambla Salada was mainly affiliated to phylum Proteobacteria and Firmicutes (72.5 and 25.8\%, respectively) (Luque et al., 2014). The genus Halomonas and Marinobacter within phylum Proteobacteria were the predominant ( 40 and 13\% respectively), whilst Bacillus genus was the most prevalent within phylum Firmicutes. In this work using DGGE, the Halomonas genus was not detected; instead this taxon is the easiest isolated in hypersaline 
environments. However, Halomonas was detected by DGGE in Rambla Salada using specific primers (Oueriaghli et al., 2014).

Extinction culturing methods have evolved from most probable number (MPN) techniques, where highest positive dilutions of MPN or dilution series provide enrichments, or even pure cultures, of abundant but fastidious bacteria that are often undetected by conventional culturing methods (Yang et al., 2016). Nutrient composition also determines the profile of the microbes that can be recovered on artificial media. Excessive nutrient concentrations are atypical in natural environments and can inhibit growth of bacteria adapted to oligotrophic conditions when they are transferred to high nutrient concentrations (Sait et al., 2002; Janssen, 2009). Adaptations to low substrate concentrations in natural environments likely have been a major factor contributing to bacterial unculturability. To address this limitation, novel media modifying the key parameters that simulate the environment (e.g., amount of nutrients, nutrient composition, the presence of trace elements, and $\mathrm{pH}$ ) have been designed for optimized bacterial growth. Furthermore, nutrient-rich media favoring colonies of fast-growing bacteria can inhibit colony formation of slower growing species and negatively affects the recovery of difficult-to-culture organisms. Therefore, low nutrient media, combined with long incubation periods at relatively low temperatures and $\mathrm{pH}$ adjustments can allow bacteria with slow growth rates to form colonies; a great range of bacteria obtained with this approach have proved to be novel organisms (Kenters et al., 2011; Yang et al., 2016).

Dilution-to-extinction approach in combination with S3 lownutrient-medium (Sait et al., 2002, 2006) and long incubation periods at $25^{\circ} \mathrm{C}$, allowed us to obtain 354 isolates, after re-isolation the positives wells in $\mathrm{R} 2 \mathrm{~A}$ medium plates. The results showed an increment in the cultivability percentages (Figure 3) compared to those obtained by classical isolation techniques. By the dilution-to-extinction technique we obtained isolates belonging to Proteobacteria (81.9\%), Firmicutes (11.3\%), Actinobacteria (4.5\%), and Bacteroidetes (2.2\%), while Luque et al. (2014) found the same phyla but different percentages (72.5, $25.8,1.4$, and 0.3 , respectively). Using dilution-to-extinction technique, we were able to isolate more bacteria belonging to phyla Actinobacteria and Bacteroidetes than those obtained by classical culture media. However with both techniques the main isolated genera were the same, Halomonas and Marinobacter. Cyanobacteria members, detected by DGGE, were not isolated by any of both methods, probably due to culture conditions used.

Using dilution-to-extinction method, we obtained 9 isolates that showed less than $97 \%$ 16S sequence identity and may well represent new taxa. Recently, one of this species belonging to the genus Blastomonas, B. quesadae has been characterized (Castro et al., 2017).

To determine the number of bacteria at Rambla Salada, we carried out a direct count using CARD-FISH and universal

\section{REFERENCES}

Abdallah M. B., Karray, F., Mhiri, N., Mei, N., Quéméneur, M., Cayol, J. L., et al. (2016). Prokaryotic diversity in a Tunisian hypersaline lake, Chott El Jerid. Extremophiles 20, 125-138. doi: 10.1007/s00792-015-0805-7 bacterial probe. The results showed the highest counts in February $2007\left(4.8 \times 10^{8}\right.$ cells $\left./ \mathrm{ml}\right)$. These results agreed with the ones obtained by DGGE and diversity indexes. The percentage of bacteria found in the different sampling areas and seasons ranged from 54.3 to $78.9 \%$ of the total prokaryotic population. These results were similar to that found in a hypersaline deposit in the Canadian High Arctic (Niederberger et al., 2010). The cultivable bacteria counted in Rambla Salada ranged from $10^{6}$ to $10^{7} \mathrm{CFU} / \mathrm{ml}$ (Luque et al., 2014), which only represents $1 \%$ of the total bacterial population detected by molecular methods.

In conclusion, the methods combination used in this study allow us to demonstrate a reliable description of the bacterial populations in the different sampling areas at Rambla Salada, and to find new uncultured taxa so far. Moreover, we shown the correlation of environmental variables with the dominance of several phylum and we demonstrate that the predominant taxa found by DGGE aren't correlated with those isolated by dilution to extinction techniques. Our study highlights and confirms the relevance of this habitat as a diversity reservoir described previously using culture-dependent approach (Luque et al., 2014).

\section{AUTHOR CONTRIBUTIONS}

NO performed the experimental DGGE techniques and statistical analysis. DC performed the experimental dilution-to-extinction techniques. IL performed the design of dilution-to-extinction technique and comparative study with culturable methods. VB performed the design of DGGE study and analysis of DGGE results. FM-C performed the design of DGGE study and dilutionto extinction technique and executed the analysis of the results and drafting of the manuscript.

\section{FUNDING}

This research was supported by grants from the Dirección General de Investigación Científica y Técnica (CGL2005-05947; CGL2008-02399; CGL2011-25748), Ministerio de Economía y Competitividad and from the Plan Andaluz de Invesigacion (P07-CVI-03150; CVI06226), Spain.

\section{ACKNOWLEDGMENTS}

The authors are very grateful to Kadiya Calderón (UGR) for her valuable assistance with the statistical analyses. We thank the Centro de Instrumentacion Cientifica of the University of Granada for their microscopy (CLSM) service. We also thank David Porcel for his suggestions about the instructions concerning the Microscopy (CLSM).

Aguirre-Garrido, J. F., Ramírez-Saad, H. C., Toro, N., and Martínez-Abarco, F. (2016). Bacterial diversity in the soda saline crater lake from Isabel island, Mexico. Microb. Ecol. 71, 68-77. doi: 10.1007/s00248-015-0676-6

Altschul, S. F., Madden, T. L., Schaffer, A. A., Zhang, J. H., Zhang, Z., Miller, W., et al. (1997). Gapped BLAST and PSI-BLAST: a new generation 
of protein data base search programs. Nucleic Acids Res. 25, 3389-3402. doi: 10.1093/nar/25.17.3389

Amann, R., and Bernhard, M. (2008). Single-cell identification in microbial communities by improved fluorescence in situ hybridization techniques. Nat. Microbiol. 6, 339-348. doi: 10.1038/nrmicro1888

Amann, R., Wolfgang, L., and Schleifer, K. H. (1995). Phylogenetic identification and in situ detection of individual microbial cells without cultivation. Microbiol. Rev. 59, 143-169.

Antón, J., Llobet-Brossa, E., Rodríguez-Valera, F., and Amann, R. (1999). Fluorescencein situ hybridization analysis of the prokaryotic community inhabiting crystallizer ponds. Environ. Microbiol. 1, 517-523. doi: 10.1046/j.1462-2920.1999.00065.x

Antón, J., Rosselló-Mora, R., Rodríguez-Valera, F., and Amann, R. (2000). Extremely halophilic Bacteria in crystallizer ponds from solar salterns. Appl. Environ. Microbiol. 66, 3052-3057. doi: 10.1128/AEM.66.7.3052-3057.2000

Bell, E. M., and Callaghan, T. V. (2012). "What are extreme environments and what lives in them?", in Life at Extremes: Environments, Organisms and Strategies for Survival, ed E. M. Bell (Wallingford: CAB International), 1-12.

Benlloch, S., López-López, A., Casamayor, E. O., Ovreas, L., Goddard, V., Daae, F. L., et al. (2002). Prokaryotic genetic diversity throughout the salinity gradient of a coastal solar saltern. Environ. Microbiol. 4, 349-360. doi: 10.1046/j.1462-2920.2002.00306.x

Besemer, K., Moeseneder, M. M., Arrieta, J. M., Herndl, G. J., and Peduzzi, P. (2005). Complexity of bacterial communities in a river-floodplain system (Dnube, Austria). Appl. Environ. Microbiol. 71, 609-620. doi: 10.1128/AEM.71.2.609-620.2005

Böckelmanna, U., Manz, W., Neu, T. R., and Szewzyk, U. (2000). Characterization of the microbial community of lotic organic aggregates ('river snow') in the Elbe river of Germany by cultivation and molecular methods. FEMS Microbiol. Ecol. 33, 157-170. doi: 10.1111/j.1574-6941.2000.tb00738.x

Brümmer, I. H. M., Fehr, W., and Wagner-Dobler, I. (2000). Biofilm community structure in polluted rivers: abundance of dominant phylogenetic groups over a complete annual cycle. Appl. Environ. Microbiol. 66, 3078-3082. doi: 10.1128/AEM.66.7.3078-3082.2000

Bruns, A., Nubel, U., Cypionka, H., and Overmann, J. (2003). Effect of signal compounds and incubation conditions on the culturability of freshwater bacterioplankton. Appl. Environ. Microbiol. 69, 1980-1989. doi: 10.1128/AEM.69.4.1980-1989.2003

Button, D. K., Schut, F., Quang, P., Martin, R., and Robertson, B. R. (1993). Viability and isolation of marine bacteria by dilution culture: theory, procedures, and initial results. Appl. Environ. Microbiol. 59, 881-891.

Castro, D. J., Cerezo, I., Sampedro, I., and Martínez-Checa, F. (2018). Roseovarius ramblicola sp. nov., a moderately halophilic bacterium isolated from saline soil in Spain. Int. J. Syst. Evol. Microbiol. 68, 1851-1856. doi: 10.1099/ijsem.0.002744

Castro, D. J., Llamas, I., Béjar, V., and Martínez-Checa, F. (2017). Blastomonas quesadae sp. nov., isolated from a saline soil by dilutionto-extinction cultivation. Int. J. Syst. Evol. Microbiol. 67, 2001-2007. doi: 10.1099/ijsem.0.001902

Connon, S. A., and Giovannoni, S. J. (2002). High-throughput methods for culturing microorganisms in very-low-nutrient media yield diverse new marine isolates. Appl. Environ. Microbiol. 68, 3878-3885. doi: 10.1128/AEM.68.8.3878-3885.2002

Curtis, T. P., Sloan, W. T., and Scannell, J. W. (2002). Estimating prokaryotic diversity and its limits. Proc. Natl. Acad. Sci. U.S.A. 99, 10494-10499. doi: 10.1073/pnas.142680199

da Rocha, U. N., van Overbeek, L., and van Elsas, J. D. (2009). Exploration of hitherto-uncultured bacteria from the rhizosphere. FEMS Microbiol. Ecol. 69, 313-328. doi: 10.1111/j.1574-6941.2009.00702.x

Davis, K. E., Joseph, S. J., and Janssen, P. H. (2005). Effects of growth medium, inoculum size, and incubation time on culturability and isolation of soil bacteria. Appl. Environ. Microbiol. 71, 826-834. doi: 10.1128/AEM.71.2.826-834.2005

del Giorgio, P. A., and Bouvier, T. C. (2002). Linking the physiologic and phylogenetic successions in free-living bacterial communities along an estuarine salinity gradient. Limnol. Oceanogr. 47, 471-486. doi: 10.4319/lo.2002.47.2.0471

Demergasso, C., Casamayor, E. O., Chong, G., Galleguillos, P., Escudero, L., and Pedrós-Alió, C. (2004). Distribution of prokaryotic genetic diversity in athalassohaline lakes of the Atacama Desert, Northern Chile. FEMS Microbiol. Ecol. 48, 57-69. doi: 10.1016/j.femsec.2003.12.013

Demergasso, C., Escudero, L., Casamayor, E. O., Chong, G., Balague, V., and Perdrós-Alió, C. (2008). Novelty and spatio-temporal heterogeneity in the bacterial diversity of hypersaline Lake Tebenquiche (Salar de Atacama). Extremophiles 12, 491-504. doi: 10.1007/s00792-008-0153-y

Dong, H., Zhang, G., Jiang, H., Yu, B., Leah, R. C., Courtney, R. L., et al. (2006). Microbial diversity in sediment of saline Qinghai Lake, China: linking geochemical controls to microbial ecology. Microbiol. Ecol. 51, 65-82. doi: 10.1007/s00248-005-0228-6

Edwards, U., Rogall, T., Blocker, H., Emde, M., and Bottger, E. C. (1989). Isolation and direct complete nucleotide determination of entire genes characterization of a gene coding for 16S-ribosomal RNA. Nucleic Acids Res. 17, 7843-7853. doi: 10.1093/nar/17.19.7843

Ferrari, B. C., Binnerup, S. J., and Gillings, M. (2005). Microcolony cultivation on a soil substrate membrane system selects for previously uncultured soil bacteria. Appl. Environ. Microbiol. 71, 8714-8720. doi: 10.1128/AEM.71.12.8714-8720.2005

Ferrari, B. C., and Gillings, M. R. (2009). Cultivation of fastidious bacteria by viability staining and micromanipulation in a soil substrate membrane system. Appl. Environ. Microbiol. 75, 3352-3354. doi: 10.1128/AEM.02407-08

Ferrari, B. C., Winsley, T., Gillings, M., and Binnerup, S. (2008). Cultivating previously uncultured soil bacteria using a soil substrate membrane system. Nat. Protoc. 3, 1261-1269. doi: 10.1038/nprot.2008.102

Gareeb, A. P., and Setati, M. E. (2009). Assessment of alkaliphilic haloarchaeal diversity in Sua pan evaporator ponds in Botswana. Afr. J. Biotechnol. 8, 259-267. doi: 10.5897/AJB2009.000-9046

Garofalo, C., Bancalari, E., Milanović, V., Cardinali, F., Osimani, A., Sardaro, M. L. S., et al. (2017). Study of the bacterial diversity of foods: PCR-DGGE versus LHPCR. Int. J. Food Microbiol. 242, 24-36. doi: 10.1016/j.ijfoodmicro.2016.11.008

Gavrish, E., Bollmann, A., Epstein, S., and Lewis, K. (2008). A trap forin situ cultivation of filamentous actinobacteria. J. Microbiol. Methods 72, 257-262. doi: 10.1016/j.mimet.2007.12.009

González-Domenech, C. M., Martínez-Checa, F., Quesada, E., and Béjar, V. (2008). Halomonas cerina sp. nov., a moderately halophilic, denitrifying, exopolysaccharide-producing bacterium. Int. J. Syst. Evol. Microbiol. 58, 803-809. doi: 10.1099/ijs.0.65322-0

Henriques, I. S., Alves, A., Tacao, M., Almeida, A., Cunha, A., and Correia, A. (2006). Seasonal and spatial variability of free-living bacterial community composition along an estuarine gradient (Ria de Aveiro, Portugal). Estuar. Coast. Shelf Sci. 68, 139-148. doi: 10.1016/j.ecss.2006.01.015

Hewson, I., Steele, J. A., Capone, D. G., and Fuhrman, J. A. (2006a). Temporal and spatial scales of variation in bacterioplankton assemblages of oligotrophic surface waters. Mar. Ecol. Prog. Ser. 311, 67-77. doi: 10.3354/meps 311067

Hewson, I., Steele, J. A., Capone, D. G., and Fuhrman, J. A. (2006b). Remarkable heterogeneity in meso and bathypelagic bacterioplankton assemblage composition. Limnol. Oceanogr. 51, 1274-1283. doi: 10.4319/lo.2006.51.3.1274

Hollister, E. B., Amanda, S. E., Hammett, A. J. M., Provin, T. L., Wilkinson, H. H., and Gentry, T. J. (2010). Shifts in microbial community structure along an ecological gradient of hypersaline soils and sediments. ISME J. 4, 829-838. doi: 10.1038/ismej.2010.3

Huang, W. C., Tsai, H. C., Tao, C. W., and Chen, J. S., Shih, Y. J., Kao, et al. (2017). Approach to determine the diversity of Legionella species by nested PCR-DGGE in aquatic environments. PLoS ONE 12:e0170992. doi: 10.1371/journal.pone.0170992

Humayun, S. B., Bano, N., and Hollibaugh, J. T. (2003). Depth distribution of microbial diversity in Mono Lake, a meromictic soda lake in California. Appl. Environ. Microbiol. 69, 1030-1042. doi: 10.1128/AEM.69.2.1030-1042.2003

Huys, G., and Swings, J. (1999). Evaluation of a fluorescent amplified fragment length polymorphism (FAFLP) methodology for the genotypic discrimination of Aeromonas taxa. FEMS Microbiol. Lett. 177, 83-92. doi: 10.1111/j.1574-6968.1999.tb13717.x

Janssen, P. H. (2009). Dormant microbes: scouting ahead or plodding along? Nature 458, 831-831. doi: 10.1038/458831a

Jiang, H., Dong, H., Yu, B., Li, Y., Ji, S., Liu, X., et al. (2007). Microbial response to salinity change in Lake Chaka, a hypersaline lake on Tibetan Plateau. Environ. Microbiol. 9, 2603-2621. doi: 10.1111/j.1462-2920.2007.01377.x 
Jiang, H., Dong, H., Zhang, G., Yu, B., Chapman, L. R., and Fields, M. W. (2006). Microbial diversity in water and sediment of Lake Chaka: an athalassohaline lake in northwestern China. Appl. Environ. Microbiol. 72, 3832-3845. doi: 10.1128/AEM.02869-05

Joseph, S. J., Hugenholtz, P., Sangwan, P., Osborne, C. A., and Janssen, P. H. (2003). Laboratory cultivation of widespread and previously uncultured soil bacteria. Appl. Environ. Microbiol. 69, 7210-7215. doi: 10.1128/AEM.69.12.7210-7215.2003

Kenters, N., Henderson, G., Jeyanathan, J., Kittelmann, S., and Janssen, P. H. (2011). Isolation of previously uncultured rumen bacteria by dilution to extinction using a new liquid culture medium. J. Microbiol. Methods 84, 52-60. doi: 10.1016/j.mimet.2010.10.011

Kirchman, D. L., Dittel, A. I., Malmstrom, R. R., and Cottrell, M. T. (2005). Biogeography of major bacterial groups in the Delaware Estuary. Limnol. Oceanogr. 50, 1697-1706. doi: 10.4319/lo.2005.50.5.1697

Koch, I. H., Gich, F., Dunfield, P. F., and Overmann, J. (2008). Edaphobacter modestus gen. nov., sp nov., and Edaphobacter aggregans sp nov., acidobacteria isolated from alpine and forest soils. Int. J. Syst. Evol. Microbiol. 58, 1114-1122. doi: 10.1099/ijs.0.65303-0

Kumar, S., Stecher, G., and Tamura, K. (2016). MEGA7: Molecular Evolutionary Genetics Analysis version 7.0 for bigger datasets. Mol. Biol. Evol. 33, 1870-1874. doi: 10.1093/molbev/msw054

Langenheder, S., Kisand, V., Wikner, J., and Tranvik, L. J. (2003). Salinity as a structuring factor for the composition and performance of bacterioplankton degrading riverine DOC. FEMS Microbiol. Ecol. 45, 189-202. doi: 10.1016/S0168-6496(03)00149-1

Lepš, J., and Šmilauer, P. (2003). Multivariate Analysis of Ecological Data Using CANOCO. Cambridge: Cambridge University Press.

López-López, A., Yarza, P., Richter, M., Suárez-Suárez, A., Antón, J., Niemann, H., et al. (2010). Extremely halophilic microbial communities in anaerobic sediments from a solar saltern. Environ. Microbiol. Rep. 2, 258-271. doi: 10.1111/j.1758-2229.2009.00108.x

Luque, R., Béjar, V., Quesada, E., and Llamas, I. (2014). Diversity of halophilic bacteria isolated from Rambla Salada, Murcia (Spain). Can. J. Microbiol. 60, 839-846. doi: 10.1139/cjm-2014-0342

Luque, R., Béjar, V., Quesada, E., Martínez-Checa, F., and Llamas, I. (2012a). Halomonas ramblicola sp. nov., a moderately halophilic bacterium from Rambla Salada, a mediterranean hypersaline rambla in south-east Spain. Int. J. Syst. Evol. Microbiol. 62, 2903-2909. doi: 10.1099/ijs.0.039453-0

Luque, R., González-Domenech, C. M., Llamas, I., Quesada, E., and Béjar, V. (2012b). Diversity of culturable halophilic archaea isolated from Rambla Salada, Murcia (Spain). Extremophiles 16, 205-213. doi: 10.1007/s00792-011-0420-1

Magurran, A. E. (1996). Ecological Diversity and its Measurement. London: Chapman and Hall.

Makhdoumi-Kakhki, A., Amoozegar, M. A., and Ventosa, A. (2012). Salinibacter iranicus sp. nov. and Salinibacter luteus sp. nov., isolated from a salt lake, and emended descriptions of the genus Salinibacter and of Salinibacter ruber. Int. J. Syst. Evol. Microbiol. 62, 1521-1527. doi: 10.1099/ijs.0.031971-0

Martínez-Cánovas, M. J., Béjar, V., Martínez-Checa, F., Páez, R., and Quesada, E. (2004). Idiomarina fontislapidosi sp. nov. and Idiomarina ramblicola sp. nov., isolated from inland hypersaline habitats in Spain. Int. J. Syst. Evol. Microbiol. 54, 1793-1797. doi: 10.1099/ijs.0.63172-0

Marzorati, M., Wittebolle, L., Boon, N., Daffonchio, D., and Verstraete, W. (2008). How to get more out of molecular fingerprints, practical tools for microbial ecology. Environ. Microbiol. 10, 1571-1581. doi: 10.1111/j.1462-2920.2008.01572.x

Maturrano, L., Santos, F., Rosselo-Mora, R., and Antón, J. (2006). Microbial Diversity in Maras salterns, a hypersaline environment in the Peruvian Andes. Appl. Environ. Microbiol. 72, 3887-3895. doi: 10.1128/AEM.02214-05

Mesbah, N. M., Abou-El-Ela, S. H., and Wiegel, J. (2007). Novel and unexpected prokaryotic diversity in water and sediments of the alkaline, hypersaline lakes of the Wadi An Natrun, Egypt. Microb. Ecol. 54, 598-617. doi: 10.1007/s00248-006-9193-y

Mouné, S., Caumette, P., Matheron, R., and Willison, J. C. (2003). Molecular sequence analysis of prokaryotic diversity in the anoxic sediments underlying cyanobacterial mats of two hypersaline ponds in Mediterranean salterns. FEMS Microbiol. Ecol. 44, 117-130. doi: 10.1016/S0168-6496(03)00017-5
Muller, D. W., and Hsü, K. J. (1987). Event stratigraphy and paleoceanography in the Fortuna basin (Southeast Spain): a scenario for the Messinian salinity crisis. Paleoceanogr 2, 679-696. doi: 10.1029/PA002i006p 00679

Mutlu, M. B., and Güven, K. (2015). Bacterial diversity in Çamalti Saltern, Turkey. Pol. J. Microbiol. 64, 37-45.

Mutlu, M. B., Martínez-García, M., Santos, F., Peña, A., Guven, K., and Antón, J. (2008). Prokaryotic diversity in Tuz Lake, a hypersaline environment in Inland Turkey. FEMS Microbiol. Ecol. 65, 474-483. doi: 10.1111/j.1574-6941.2008.00510.x

Muyzer, G., and De Waal, E. C. (1994). "Determination of the genetic diversity of microbial communities using DGGE analysis of PCR-amplified 16S rDNA," in Microbial Mats: Structure, Development and Environmental Significance, ed L. J. Stal and P. Caumette (Heidelberg: Springer-Verlag), 207-214.

Muyzer, G., De Waal, E. C., and Uitterlinden, A. G. (1993). Profiling of complex microbial populations by 16 denaturing gradient gel electrophoresis analysis of polymerase chain reaction-amplified genes coding for 16S rRNA. Appl. Environ. Microbiol. 59, 695-700.

Muyzer, G., Hottentra-Ger, S., Teske, A., and Wawer, C. (1996). "Denaturing gradient gel electrophoresis of PCR-amplified 16S rDNA a new molecular approach to analyse the genetic diversity of mixed microbial communities," in Molecular Microbial Ecology Manual, ed A. D. L. Akkermans, J. D. van Elsas and F. J. de Bruijn (Dordrecht: Kluwer Academic Publishers), 1-23.

Nemergut, D. R., Costello, E. K., Hamady, M., Lozupone, C., Jiang, L., Schmidt, S. K., et al. (2011). Global patterns in the biogeography of bacterial taxa. Environ. Microbiol. 13, 135-144. doi: 10.1111/j.1462-2920.2010.02315.x

Neufeled, J. D., and Mohn, W. W. (2006). “Assessment of microbial phylogenetic diversity based on environmental nucleic acid," in Molecular Identification Systematic and Population Structure of Prokaryotes, ed E. Stackebrandt (Berlin: Springer-Verlag), 220-259.

Niederberger, T. D., Perreault, N. N., Tille, S., Lollar, B. S., Lacrampe-Couloume, G., Andersen, D., et al. (2010). Microbial characterization of a subzero, hypersaline methane seep in the Canadian High Arctic. Int. J. Syst. Evol. Microbiol. 4, 1326-1339. doi: 10.1038/ismej.2010.57

Oren, A. (2002). Halophilic Microorganisms and Their Environments. Dordrecht: Kluwer Academic.

Oren, A. (2003). Molecular ecology of extremely halophilic Archaea and Bacteria. FEMS Microbiol. Ecol. 39, 1-7. doi: 10.1111/j.1574-6941.2002.tb0 0900.x

Oren, A. (2007). "Biodiversity in highly saline environments," in Physiology and Biochemistry of Extremophiles, eds C. Gerday and N Glansdorff (Washington, DC: ASM Press), 223-231.

Oren, A. (2011). Thermodynamic limits to microbial life at high salt concentrations. Environ. Microbiol. 13, 1908-1923. doi: 10.1111/j.1462-2920.2010.02365.x

Oueriaghli, N., Béjar, V., Quesada, E., and Martínez-Checa, F. (2013). Molecular ecology techniques reveal both spatial and temporal variations in the diversity of archaeal communities within the athalassohaline environment of Rambla Salada, Spain. Microl. Ecol. 66, 297-311. doi: 10.1007/s00248-0130176-5

Oueriaghli, N., González-Domenech, C. M., Martínez-Checa, F., Muyzer, G., Ventosa, A., Quesada, E., et al. (2014). Diversity and distribution of Halomonas in Rambla Salada, a hypersaline environment in the southeast of Spain. FEMS Microbiol. Ecol. 87, 460-474. doi: 10.1111/1574-6941.12237

Panosyan, H., Hakobyan, A., Birkeland, N. K., and Trchounian, A. (2018). Bacilli community of saline-alkaline soils from the Ararat Plain (Armenia) assessed by molecular and culture-based methods. Syst. Appl. Microbiol. 41, 232-240. doi: 10.1016/j.syapm.2017.12.002

Pernthaler, A., Pernthaler, J., and Amann, R. (2002). Fluorescence in situ hybridization and catalyzed reporter deposition for the identification of marine bacteria. Appl. Environ. Microbiol. 68, 3094-3101. doi: 10.1128/AEM.68.6.3094-3101.2002

Ramírez-Díaz, L., Vidal-Abarca, M. R., Calvo, J. F., Suarez, M. L., Palazón, J. A., Esteve, M. A., et al. (1995). Bases Ecológicas Para la Delimitación, Ordenación y Gestión del Paisaje Protegido de las Ramblas de Ajauque y Salada, Vol 1 and 2, Murcia: Consejería de Medio Ambiente, Comunidad Autónoma de la Región de Murcia, Spain. 
Rappé, M. S., and Giovannoni, S. J. (2003). The uncultured microbial majority. Аnnu. Rev. Microbiol. 57, 369-394. doi: 10.1146/annurev.micro.57.030502.090759

Reasoner, D. J., and Geldreich, E. E. (1985). A new medium for the enumeration and subculture of bacteria from potable water. Appl. Environ. Microbiol. 49, $1-7$.

Rhasband, W. (2010). The ImageJ (Image processing and Analysis in Java) Version 1.43u. National Institutes of Health, USA. Available online at: http://rsb.info. nih.gov/ij/

Rodriguez-Valera, F., Ruiz-Berraquero, F., and Ramos-Cormenzana, A. (1981). Characteristics of heterotrophic bacterial populations in hypersaline environments of different salt concentrations. Microb. Ecol. 7, 235-243. doi: $10.1007 / \mathrm{BF} 02010306$

Rosselló-Mora, R., Lee, N., Antón, J., and Wagner, M. (2003). Substrate uptake in extremely halophilic microbial communities revealed by microautoradiography and fluorescencein situ hybridization. Extremophiles 7, 409-413. doi: 10.1007/s00792-003-0336-5

Sait, M., Davis, K. E., and Janssen, P. H. (2006). Effect of $\mathrm{pH}$ on isolation and distribution of members of subdivision 1 of the phylum Acidobacteria occurring in soil. Appl. Environ. Microbiol. 72, 1852-1857. doi: 10.1128/AEM.72.3.1852-1857.2006

Sait, M., Hugenholtz, P., and Janssen, P. H. (2002). Cultivation of globally distributed soil bacteria from phylogenetic lineages previously only detected in cultivation-independent surveys. Environ. Microbiol. 4, 654-666. doi: 10.1046/j.1462-2920.2002.00352.x

Salles, J. F., Van Veen, J. A., and Van Elsas, J. D. (2004). Multivariate analyses of Burkholderia species in soil: effect of crop and land use history. Appl. Environ. Microbiol. 70, 4012-4020. doi: 10.1128/AEM.70.7.4012-4020.2004

Sapp, M., Wichels, A., Wiltshire, K., and Gerdts, G. (2007). Bacterial community dynamics during the winter-spring transition in the North Sea. FEMS Microbiol. Ecol. 59, 622-637. doi: 10.1111/j.1574-6941.2006.00238.x

Schoenborn, L., Yates, P. S., Grinton, B. E., Hugenholtz, P., and Janssen, P. H. (2004). Liquid serial dilution is inferior to solid media for isolation of cultures representative of the phylum-level diversity of soil bacteria. Appl. Environ. Microbiol. 70, 4363-4366. doi: 10.1128/AEM.70.7.4363-4366.2004

Scholten, J. C., Joye, S. B., Hollibaugh, J. T., and Murrell, J. C. (2005). Molecular analysis of the sulfate reducing and archaeal community in a meromictic soda lake (Mono Lake, California) by targeting $16 \mathrm{~S}$ rRNA, mcrA, apsA, and dsrAB genes. Microbiol. Ecol. 50, 29-39. doi: 10.1007/s00248-004-0085-8

Schwalbach, M., Brown, M., and Fuhrman, J. (2005). Impact of light on marine bacterioplankton community structure. Aquat. Microbiol. Ecol. 39, 235-245. doi: 10.3354/ame039235

Shannon, C. E., and Weaver,W. (1963). The Mathematical Theory of Communication. Urbana, IL: University of Illinois Press.

Snaidr, J., Amann, R., Huber, I., Ludwig, W., and Schleifer, K. H. (1997). Phylogenetic analysis andin situ identification of bacteria in activated sludge. Appl. Environ. Microbiol. 63, 2884-2896.

Sokal, R. R., and Rohlf, F. J. (1962). The comparison of dendrograms by objective methods. Taxon 11, 33-40. doi: 10.2307/1217208

Stevenson, B. S., Eichorst, S. A., Wertz, J. T., Schmidt, T. M., and Breznak, J. A. (2004). New strategies for cultivation and detection of previously uncultured microbes. Appl. Environ. Microbiol. 70, 4748-4755. doi: 10.1128/AEM.70.8.4748-4755.2004
Swan, B. K., Ehrhardt, C. J., Reifel, K. M., Moreno, L. I., and Valentine, D. L. (2010). Archaeal and bacterial communities respond differently to environmental gradients in anoxic sediments of a California hypersaline lake, the Salton Sea. Appl. Environ. Microbiol. 76, 757-768. doi: 10.1128/AEM.02409-09

Tang, W., Gong, J., Wu, L., Li, Y., Zhang, M., and Zeng, X. (2016). DGGE diversity of manganese mine samples and isolation of a Lysinibacillus sp. efficient in removal of high $\mathrm{Mn}$ (II) concentrations. Chemosphere 165, 277-283. doi: 10.1016/j.chemosphere.2016.08.134

Ventosa, A. (2004). Halophilic Microorganisms. Berlin; Heidelberg: Germany: Springer-Verlag.

Ventosa, A. (2006). "Unusual micro-organisms from unusual habitats: hypersaline environments," in Prokaryotic Diversity Mechanism and Significance, eds N. A. Logan, H. M. Lappin-Scott, and P. C. F. Oyston (Cambridge; London: Cambridge University Press), 223-254.

Ventosa, A., Mellado, E., Sanchez-Porrro, C., and Marquez, M. C. (2008). "Halophilic and halotolerant microorganisms from soils," in Microbiology of Extreme Soils, eds P. Dion and C. S. Nautiyal (Berlin: Springer-Verlag), 87-115.

Wagner, M., Horn, M., and Daims, H. (2003). Fluorescencein situ hybridisation for the identification and characterisation of prokaryotes. Curr. Opin. Microbiol. 6, 302-309. doi: 10.1016/S1369-5274(03)00054-7

Wu, Q. L., Zwart, G., Schauer, M., Kamst-van Agterveled, M. P., and Hahn, H. V. (2006). Bacterioplankton community composition along a salinity gradient of sixteen high-mountain Lakes located on the Tibetan plateau, China. Appl. Environ. Microbiol. 72, 5478-5485. doi: 10.1128/AEM.00767-06

Yang, S. J., Kang, I., and Cho, J. C. (2016). Expansion of cultured bacterial diversity by large-scale dilution-to-extinction culturing from a single seawater sample. Microb. Ecol. 71, 29-43. doi: 10.1007/s00248-015-0695-3

Yin, Y., Song, W., Gu, J., Zhang, K., Qian, X., Zhang, X., et al. (2016). Effects of copper on the abundance and diversity of ammonia oxidizers during dairy cattle manure composting. Bioresour. Technol. 221, 181-187. doi: $10.1016 /$ j.biortech.2016.09.016

Zengler, K., Toledo, G., Rappé, M., Elkins, J., Mathur, E. J., Short, J. M., et al. (2002). Cultivating the uncultured. Proc. Natl. Acad. Sci. U.S.A. 99, 15681-15686. doi: $10.1073 /$ pnas.252630999

Zengler, K., Walcher, M., Clark, G., Haller, I., Toledo, G., Holland, T., et al. (2005). High-throughput cultivation of microorganisms using microcapsules. Methods Enzymol. 397, 124-130. doi: 10.1016/S0076-6879(05)97007-9

Zhang, Y., Jiao, N. Z., Cottrell, M. T., and Kirchman, D. L. (2006). Contribution of major bacterial groups to bacterial biomass production along a salinity gradient in the South China Sea. Aquat. Microb. Ecol. 43, 233-241. doi: $10.3354 / \mathrm{ame} 043233$

Conflict of Interest Statement: The authors declare that the research was conducted in the absence of any commercial or financial relationships that could be construed as a potential conflict of interest.

Copyright (C) 2018 Oueriaghli, Castro, Llamas, Béjar and Martínez-Checa. This is an open-access article distributed under the terms of the Creative Commons Attribution License (CC BY). The use, distribution or reproduction in other forums is permitted, provided the original author(s) and the copyright owner are credited and that the original publication in this journal is cited, in accordance with accepted academic practice. No use, distribution or reproduction is permitted which does not comply with these terms. 